\title{
Are the Benefits of Export Support Durable? Evidence from Tunisia\#
}

\author{
Olivier Cadot* \\ Ana M. Fernandes+ \\ Julien Gourdon§ \\ Aaditya Mattoo++ \\ Revised version, July 2015
}

\begin{abstract}
This paper evaluates the effects of the FAMEX export promotion program in Tunisia on the performance of beneficiary firms. While most studies assess only the short-term impact of such programs, we consider also the longer-term impact. Our estimates suggest that the average beneficiary initially saw both higher overall export levels and greater diversification across destinations and products. However, three years after the intervention, beneficiaries' export levels and diversification were no longer significantly different from those of a control group. Furthermore, the effects were heterogeneous across firms: small and large firms saw no positive impact on export levels, and even the positive impact on medium sized firms was temporary. The temporariness of the impact was not due to spillovers to non-beneficiary firms which helped them to catch up, or to greater exposure of beneficiaries to crisis-affected economies. Rather, the impact may be transient because the program did not lead to the enhancements in product quality or sophistication which could have strengthened competitiveness durably. Notwithstanding its transient effect, the relatively low-cost FAMEX still generated two Tunisian Dinars of private profits per Dinar of program expenditure, and the additional corporate tax revenue just covered the public cost of the program.
\end{abstract}

JEL classification codes: F13, F14, L15, L25, 017, 024, C23.

Keywords: Export promotion, firms, export margins, Tunisia, impact evaluation, propensity-score matching, matching grant.

\footnotetext{
\# The authors are especially grateful to two anonymous referees and the editor for their very useful suggestions. The paper is a substantially modified version of the 2012 World Bank working paper with the same title. We are also grateful to Hamid Alavi, Jeronimo Carballo, Tani Fukui, Alan Gelb, Beata Javorcik, Daniel Lederman, Jean-Michel Marchat, Mine Senses, and Christian Volpe, for their useful comments and discussions, to Yasusuki Todo for sharing his matching methodology and to participants at CEPII, the Center for Economic Studies at the U.S. Census Bureau, the 2011 Conference on Trade and Firms in Aix en Provence, the 2011 World Bank-IGC workshop on "Trade policy for growth", the 2012 International Industrial Organization Conference, the Nova School of Business and Economics, the Paris School of Economics, the 2011 Southern Economic Association Meetings, the University of Lausanne, the University of Illinois at Urbana-Champaign, the 2012 FERDI-ITC-World Bank workshop on "Aid for Trade: What Have we Learnt? Which way Ahead?," the 2012 IDB Workshop on the Effects of Trade and Investment Promotion, the 2013 Summer Meetings of the Econometric Society, and the World Bank workshop of the Chief Economist of the Middle East and North Africa Region for comments. We are particularly thankful to Bob Rijkers and Hassen Arouri at Tunisia's National Statistical Institute for providing us with statistics on firms' profit margins. Research for this paper has been supported in part by the World Bank's Multidonor Trust Fund for Trade and Development and through the Strategic Research Partnership on Economic Development as well as by Switzerland's SNF through NCCR work package 6 on impact assessment, and by France's Agence Nationale de la Recherche under grants ANR-10-LABX-14-01 and ANR-12-JSH1-0002-01. The findings expressed in this paper are those of the authors and do not necessarily represent the views of the World Bank.

* University of Lausanne, CEPR and FERDI, Swizerland.

+ Development Economics Research Group, World Bank, United States.

$\S$ CEPII, France.

${ }^{++}$Development Economics Research Group, World Bank, United States.
} 


\section{Introduction}

Since trade liberalization per se has not always led to improved export performance, the focus of trade policy has shifted in recent years toward trade facilitation and export promotion. Significant resources are being devoted to export-processing zones, exporter assistance programs, and projects aimed at modernizing border management and customs procedures even though there is not much evidence of their impact. This paper contributes to the nascent literature on the evaluation of targeted export-assistance programs by assessing the firm-level effects of a recent export promotion program in Tunisia. Whereas existing evaluations typically focus on the contemporaneous or short-term effect of interventions, we also assess the longer-term impact. ${ }^{1}$ Furthermore, while evaluations usually only assess whether a program works, we consider also alternative explanations for the observed results.

The literature assessing the effectiveness of export promotion has developed along two strands. The older one relies on cross-country evidence and examines effects on aggregate export performance. Thus, Rose (2007) used a gravity equation to show that diplomatic representations had a positive effect on bilateral trade flows. Lederman, Olarreaga, and Payton (2010) showed that export promotion activities, after a long history of failure, in particular in developing countries where they coexisted with import substitution policies and currency overvaluation, had recently more success in increasing aggregate exports, particularly when the private sector was involved in the management of promotion activities. ${ }^{2}$

A more recent strand of the literature has evaluated export promotion programs using quasiexperimental methods, comparing the export performance of treated firms with that of a control group. Since enrollment into export promotion programs is not random, most papers control for selection through matching, fixed effects, or two-step (instrumental variables or Heckman) estimation methods. The first broad finding is that export promotion seems to be more successful at improving the performance of established exporters than at encouraging non-exporters to start exporting (Bernard and Jensen, 2004; Görg, Henry and Strobl, 2008; Girma, Gong, Görg and Yu, 2009). This is consistent with the literature on heterogeneous firms and trade, which suggests that exporters and non-exporters differ in terms of productivity and a host of other firm characteristics (see, e.g. Bernard, Jensen, Redding and Schott, 2007) which export promotion may not be able to affect. The second broad finding is that for established exporters, the impact is stronger along the

\footnotetext{
${ }^{1}$ This helps correct what Ravallion (2008) has called the "myopia bias", whereby evaluation that focused on short-term effects may tilt incentives toward development projects that yield quick results.

2 The authors regress country-level exports per capita on the budgets of export-promotion agencies (also per capita) and a host of country-level control variables. The agencies' budgets are instrumented with the agencies' age and interacted, inter alia, with management modes, one of which is private sector involvement.
} 
extensive margin than along the intensive one (Alvarez and Crespi, 2000, Volpe and Carballo, 2008), ${ }^{3}$ suggesting that assistance may be more successful in helping firms overcome hurdles to break into new markets (product- or destination-wise) than in ramping up export volumes. ${ }^{4}$ These papers break new ground in terms of rigorous evaluation of trade interventions, but focus primarily on the short-term effects of interventions. To our knowledge, the only paper that looks explicitly at the lingering effects of export promotion is van Biesebroeck, Yu and Chen (forthcoming) who find that Canadian firms which received assistance from Canada's Trade Commissioner Services at any time in the past exported significantly more than the control group.

Our paper examines the short-term and longer-term impact of Tunisia's export promotion program, FAMEX, which provided matching grants to Tunisian firms to implement export business plans. As stated in the World Bank's Project Appraisal Document (PAD) (World Bank, 2004), FAMEX's primary objective was "to improve access to export markets", the corresponding performance indicator being "[t]otal incremental export value by the beneficiary enterprises." We use this indicator as our baseline performance outcome variable, although we explore a number of other dimensions as well, including product and destination diversification, unit values, product sophistication, and distance to destinations.

We combine several sources of firm-level data-FAMEX program data, National Statistical Institute and Investment Promotion Agency data, and customs transaction data-into a unique, rich dataset on Tunisian exporters. The inclusion in the merged dataset of customs data on exports eliminates the risk of recall bias in outcome variables, which tends to arise when public programs are evaluated ex-post using surveys. ${ }^{5}$ Our estimation method is the propensity score weighted regression method proposed by Hirano, Imbens, and Ridder (2003), where weights are obtained from a probit regression for selection into the FAMEX program that accounts for past firm export performance, and where we also include firm fixed effects.

We find that, compared to a control group, FAMEX beneficiaries initially enjoyed a boost in their total exports accompanied by greater diversification across destinations and products. However, all these effects vanished after three years. Even the temporary effect was heterogeneous across firms, being significant only for medium-sized firms (between 20 and 100 employees). We find no evidence that the temporariness of FAMEX's impact reflected spillovers to non-beneficiary

\footnotetext{
${ }^{3}$ Girma, Gong, Görg and Yu (2009) find a positive impact along the intensive margin but they consider the special case of production subsidies.

${ }^{4}$ See Rangan and Lawrence (1999) and references therein on the hurdles facing the internationalization of firms. Assistance may have stronger effects for small firms, perhaps because they face relatively greater hurdles, as Volpe and Carballo (2010) find in the case of an export promotion program in Chile.

${ }^{5}$ In the case of FAMEX, the World Bank collected firm-level survey data to analyze the impact of the program and the corresponding analysis is described in Gourdon, Marchat, Sharma, and Vishwanath (2011).
} 
firms which helped them to catch up, or greater exposure of beneficiary firms to crisis-affected economies. Rather, the impact may have been temporary because it was hard for a short-lived, arm's length FAMEX-type intervention to durably enhance competitiveness. Indeed, we found that the program did not lead to any improvements in product quality as would be reflected in higher unit prices, or in an indicator of product sophistication. Instead, it primarily benefited firms that initially had no internal export unit, suggesting that assistance was rudimentary. These findings suggest that FAMEX may have placed too much emphasis on "low-hanging fruits" (helping domestic exporters attend or set up a representation in foreign fairs) rather than on more complex activities aimed at improving products and processes, which would improve longer-term competitiveness.

In spite of FAMEX's relatively transient impact, the relatively low-cost intervention still generated about 2 Tunisian Dinars of additional profits per Dinar of expenditure on the program. The firms' benefit-cost ratio was 3.57 while the government just broke even. These estimates suggest a high degree of internalization of the benefits and raise the question of why the firms did not undertake such investments unilaterally. Of course, firms' inability to borrow against future profits or being poorly informed about the benefits of investments in export promotion, could still provide a rationale for the FAMEX program.

The paper is organized as follows. Section 2 describes the export promotion program and Section 3 presents the data. Section 4 discusses estimation issues. Section 5 presents baseline FAMEX treatment effects. Section 6 examines alternative explanations for our main results and estimates the economic magnitude of the effect. Section 7 concludes.

\section{Export promotion in Tunisia}

The Tunisian government has worked since the mid-1990s to reduce the traditional anti-export bias of Tunisia's trade policy (World Bank, 2008). Our analysis focuses on FAMEX, a major demand-driven program whose aim was to help Tunisian firms overcome barriers to sell in foreign markets and enhance their competitiveness. ${ }^{6}$ The program's rationale was that Tunisian firms were

\footnotetext{
${ }^{6}$ The FAMEX program also helped to build the institutional capacity of local professional organizations (export associations, chambers of commerce, and professional consulting organizations) and to strengthen the export consulting sector in Tunisia. Another component of the second phase of the World Bank's Export Development Project (of which FAMEX was a component) focused on trade facilitation, including investments and technical assistance to modernize customs procedures, through a combination of investments in hardware and software and procedural improvements. These components-if effective-are likely to have benefited Tunisian firms broadly and thus do not necessarily contaminate the identification of FAMEX effects. We will control in all specifications for sector-year fixed effects which should absorb the effects of those components.
} 
poorly informed about export markets and had difficulty identifying the right target markets, product segments, and sales channels.

The program provided firms with matching grants co-financing 50 percent of the cost of their export business plans. In terms of firm size, the minimum annual turnover required for FAMEX eligibility was 200,000 Tunisian Dinars (136,000 USD) in manufacturing and 100,000 Tunisian Dinars $\left(69,000\right.$ USD) in service and craft sectors. ${ }^{7}$ In terms of age, only firms that had been in operation for a minimum of two years were eligible for FAMEX, but there were a few exceptions.

A firm approaching FAMEX for assistance had to submit an export business plan focused on one of three possible objectives: (i) become a substantive exporter (if the firm had little or no export experience), (ii) to diversify its destination markets, or (iii) to develop new export products. ${ }^{8}$ While a single main objective had to be provided for each export business plan, firms could request assistance also for other objectives. The export business plan was evaluated by a panel of five local and international experts and, if accepted, the FAMEX team would help the firm improve its plan. ${ }^{9}$ The panel would draw up, together with the firm, a list of activities eligible for matching grants of up to 50 percent of their cost, with a ceiling of 100,000 Tunisian Dinars (69,000 USD).

FAMEX granted assistance to 1,060 firms between 2005 and 2009, of which 31 percent had little or no export experience while 69 percent were already exporters and wanted to diversify either by expanding into new destination markets (49 percent) or into new products (20 percent). The program's coverage was fairly broad in terms of sectors and locations (see Section 3 ).

FAMEX grants were used mostly to co-finance the cost of technical assistance and marketing services provided by local and foreign experts. Five types of activities were financed: (i) market prospection, (ii) promotion, (iii) product development, (iv) firm development, and (v) foreign subsidiary creation. The amounts disbursed by FAMEX for each type of activity along with a description of the activities are shown in Table 1. In terms of actual disbursements, shares in the program total in the second column add up to 100 percent, but the number of firms in the third column adds up to more than the total number of FAMEX beneficiaries because each firm typically received co-financing to undertake several activities. ${ }^{10}$

\footnotetext{
${ }^{7}$ Tunisian Dinars are converted to USD using the exchange rate as of October 10, 2011 (1 USD = 1.463 Tunisian Dinars).

${ }^{8}$ While there was no clear rule on which firms were deemed to have little export experience, in interviews with the authors, the FAMEX management team indicated that they included in that category firms that either did not export or exported an amount representing less than 20 percent of their total sales in the recent past.

9 The FAMEX management team did not base selection decisions on an explicit scoring framework (for example, by weighting selection criteria into a score for each FAMEX application). Instead, they used their "best judgment" for each application.

${ }^{10}$ A different breakdown of the activities in Table 1 provided by FAMEX program data indicates that 25 percent of FAMEX funds covered marketing research costs, 18 percent covered fees from private export-marketing consultants, 15 percent covered the
} 
As FAMEX was a matching-grant program in which firms contributed half the costs, the program's management team expected firms' incentives to be aligned with the program, so that grants were unlikely to be misallocated or devoted to low-value services. The fact that FAMEX operated on a reimbursement basis, whereby firms had to present receipts upon implementing the activities in their plan, gives us reasonable confidence that the matching grant funds were used for their intended purpose. ${ }^{11}$ These features of FAMEX make it a particularly attractive program to evaluate.

Table 1. FAMEX program components

\begin{tabular}{|c|c|c|c|}
\hline & Description of activities & $\begin{array}{c}\text { Amounts } \\
\text { disbursed (in } \\
\text { millions of USD) }\end{array}$ & $\begin{array}{c}\text { Share in } \\
\text { program total }\end{array}$ \\
\hline Market prospection & $\begin{array}{l}\text { Acquisition of information including for example the purchase of } \\
\text { data or trade missions abroad to visit or participate in foreign } \\
\text { exhibitions }\end{array}$ & 2.665 & $23.9 \%$ \\
\hline Promotion & $\begin{array}{l}\text { Production of information and marketing including the design, } \\
\text { production and publication of ads in various media, firm } \\
\text { representation in fairs and exhibitions, and mailings. }\end{array}$ & 4.113 & $36.9 \%$ \\
\hline Product development & $\begin{array}{l}\text { Product design modifications and production of samples and } \\
\text { package design. }\end{array}$ & 1.515 & $13.6 \%$ \\
\hline Firm development & $\begin{array}{l}\text { Training on organizational issues such as setting up a marketing } \\
\text { watch, an export cell, or an export-oriented business plan. }\end{array}$ & 1.169 & $10.5 \%$ \\
\hline Foreign subsidiary creation & $\begin{array}{l}\text { Assistance for the establishment of a facility abroad including } \\
\text { legal, consulting, covering rental and salary costs for the first } \\
\text { year of establishment. }\end{array}$ & 1.688 & $15.1 \%$ \\
\hline Total & & 11.150 & $100.0 \%$ \\
\hline
\end{tabular}

Note: Tunisian dinars were converted into U.S. dollars at the October 10, 2011 exchange rate (1.463 Tunisian Dinars per USD). The figures in the table concern the full set of 455 FAMEX beneficiaries for which data was requested to FAMEX's management team (see Section 3).

\section{Data and descriptive statistics}

In order to evaluate rigorously the impact of FAMEX, we need data on beneficiary firms as well as a control group. Our dataset combines three main sources: (i) FAMEX program data, (ii) data from the National Statistical Institute (INS in its French acronym) and the Investment Promotion Agency (API in its French acronym), and (iii) customs transaction data.

participation in trade fairs, 10 percent went to establishing foreign representations, 10 percent covered printing costs for advertising material, the rest being scattered over minor items.

${ }^{11}$ Moreover, FAMEX beneficiaries were obliged to supply the FAMEX management team with data to allow a general assessment of the project's impact on export growth, and supervision teams from the World Bank also had access to that information. However, as in the case of any assistance program, the impact of FAMEX on its stated activities could be reduced by fungibility. That is, $\$ 100$ given to a firm for a specific activity, even through a matching grant, could still have a "windfall effect" and allow the firm to re-optimize and spend less on the activity than it would have in the absence of the program. In that case, the program's money would (at least in part) replace money that the firm would have spent otherwise. 
First, we obtained from FAMEX's management team a complete list of the 1,060 beneficiary firms indexed by their tax ID. After eliminating from this list 126 firms that dropped out of the program, 163 firms in the services sector for which customs transaction data is not available, and 316 firms whose export business plan was still ongoing at the end of 2009 (the penultimate year in our sample period), we were left with 455 FAMEX beneficiaries. For these firms, we obtained program data covering the following variables: year in which the firms joined and terminated the program (which lasted for one year), firm location, sector, employment and total sales when it joined the program and when it left, whether the firm had an in-house export unit prior to joining the program, its objective in applying to FAMEX, and its grant use in terms of total disbursements and breakdown across activities.

Second, we obtained from the INS a stratified sample of control firms with a structure similar to that of the 455 FAMEX beneficiaries. The stratification was performed based on size (measured by firm employment), prior exporting status, location (Tunis versus non-Tunis) and manufacturing sub-sector, resulting in 48 cells. For each cell we asked INS to provide us with twice as many nonbeneficiaries as there were FAMEX beneficiaries, i.e., in total 910 control firms. To draw the stratified sample of control firms, INS used its 2007 census of firms which includes information on firm location, sector, date of creation, employment, and total sales, with the last two variables being defined in terms of discrete intervals. ${ }^{12}$ Since INS data was incomplete for a number of firms, we supplemented it with data obtained from the API. API's database for 2007 includes employment, sector, date of firm creation, and status (offshore or common law) for 5,000 firms across all sectors (of which 500 are also in the INS census). We extracted a group of 2,000 manufacturing firms from the API database that were neither in the FAMEX sample nor in the INS sample. ${ }^{13}$

Third, we obtained transaction-level export data from Tunisian Customs. For every year between 2000 and 2010 and for every firm (identified by its tax ID) we obtained monthly export transaction

\footnotetext{
12 The employment intervals are 1-9 employees, 10-19 employees, 20-49 employees, 50-99 employees, 100-199 employees, and more than 200 employees. The total sales intervals are: under 50,000 Tunisian Dinars, 50,000-1 million Tunisian Dinars, 1 million2 million Tunisian Dinars, 2 million-5 million Tunisian Dinars.

${ }^{13}$ We considered whether the aforementioned 126 dropouts from the FAMEX program, as well as a set of 71 firms that applied to FAMEX but were turned down, could constitute a good control group by themselves, given that they had the intention to be treated. There are several problems with this approach. First, this control group would be relatively small. Second, the available evidence suggests that this set of firms would not be a suitable control group. According to FAMEX officials, rejected applicants either were strong enough to finance their expansion plans without the matching grant; or, conversely, their financial conditions were unacceptably weak, with negative cash flow and/or inadequate capital. Thus, they were either sure to implement their plan, or poorly positioned to implement it, which makes them quite different from being "marginal" cases which could be treated as comparable to accepted ones. As for dropouts, either they did not take the grant, because they gave up their export expansion plan and communicated this to FAMEX management; or they used less than two percent of it, in which case FAMEX management dropped them from the program. Again, either they did not implement their plan with certainty or they were, like some of the FAMEX rejects, capable of carrying it out without assistance. Nevertheless, we established that the inclusion or exclusion of this set of firms from the control group did not affect our results.
} 
values by destination country and product code, the latter using an 11-digit Tunisian nomenclature derived from the Harmonized System (HS). ${ }^{14}$ We aggregated monthly data to annual export totals for each firm and year.

Combining data from all three sources, and after data consistency checks and cleaning, we obtained an unbalanced panel of yearly export activity for 2,711 exporting firms over the period 20002010. ${ }^{15}$ Of those, 392 firms benefitted from FAMEX and 2,319 did not. ${ }^{16}$ Firms benefitted from the FAMEX program in different years: 253 (the majority) received assistance in 2005, 22 received it in 2006, 75 received it in 2007, 40 received it in 2008, and 2 received it in 2009.

Our combined dataset has two positive features. First, the inclusion of customs transaction data on exports ensures that the outcome variables do not suffer from recall bias, as would be the case if the outcome variables were obtained from survey data. Second, the fact that all control firms are exporting firms (as stratification was based on prior exporting status) improves overall sample homogeneity and the identification of FAMEX effects. ${ }^{17}$ Note that in the combined dataset, firmlevel characteristics other than those related to export transactions are time-invariant, being available only for 2007 .

Table 2 provides descriptive statistics for FAMEX and control firms in terms of sector, location, and employment categories. The sectoral distribution of FAMEX and control firms is quite similar with the exception of the textiles \& apparels sector which is more heavily represented in the control group, although it is also the treatment group's largest sector, accounting for 31 percent of beneficiaries. Location was also used for stratification, hence the geographical distribution of FAMEX and control firms is fairly similar, although FAMEX firms are more concentrated in Tunis. There are also only minor differences across size categories measured in terms of employment and the same is true in terms of sales (not reported).

\footnotetext{
${ }^{14}$ When necessary the data was converted to HS 6-digit by keeping the classification's first six digits.

15 The merging of the three data sources was possible thanks to the use of unique tax IDs by all Tunisian administrations concerned and their willingness to share the data with us. Some of the data inconsistencies addressed were wrong sectoral classifications in the FAMEX program data which were corrected using INS and API data.

${ }^{16}$ The reduction in the number of FAMEX beneficiaries from 455 potential firms to 392 firms in our final sample is due to missing data on some of the key variables for our analysis, in particular on the large set of covariates that is included in the first-stage probit regression (described in Section 4).

${ }^{17}$ By "exporters", we mean firms having a customs code and having conducted at least one export transaction during the period 2000-2010.
} 
Table 2. Sample characteristics: sector, region, and employment category

Panel A. Distribution by sector

\begin{tabular}{lcccccccc}
\hline Sector & $\begin{array}{c}\text { Agro- } \\
\text { industry } \\
(\%)\end{array}$ & $\begin{array}{c}\text { Textile \& } \\
\text { apparels } \\
(\%)\end{array}$ & $\begin{array}{c}\text { Paper, } \\
\text { wood \& } \\
\text { furniture } \\
(\%)\end{array}$ & $\begin{array}{c}\text { Chemicals } \\
(\%) \& \\
\text { plastics }\end{array}$ & $\begin{array}{c}\text { Metals } \\
(\%)\end{array}$ & $\begin{array}{c}\text { Machines } \\
\text { equipment } \\
(\%)\end{array}$ & $\begin{array}{c}\text { Electronics } \\
(\%)\end{array}$ & $\begin{array}{c}\text { Total } \\
\text { number of } \\
\text { firms }\end{array}$ \\
\hline FAMEX firms & 15 & 32 & 13 & 13 & 8 & 14 & 6 & 392 \\
Control firms & 12 & 43 & 9 & 11 & 7 & 11 & 7 & 2,319 \\
\hline
\end{tabular}

Panel B. Distribution by region

\begin{tabular}{lccccc}
\hline Location & Tunis (\%) & $\begin{array}{c}\text { Grand } \\
\text { Tunis (\%) }\end{array}$ & $\begin{array}{c}\text { Central } \\
\text { Sea (\%) }\end{array}$ & $\begin{array}{c}\text { Rest of } \\
\text { Tunisia } \\
(\%)\end{array}$ & $\begin{array}{c}\text { Total } \\
\text { number of } \\
\text { firms }\end{array}$ \\
\hline FAMEX firms & 22 & 47 & 2 & 28 & 392 \\
Control firms & 9 & 46 & 8 & 37 & 2,319 \\
\hline
\end{tabular}

Panel C. Distribution by employment category

\begin{tabular}{lccccccc}
\hline Employment & $\begin{array}{c}{[1,9]} \\
(\%)\end{array}$ & $\begin{array}{c}{[10,19]} \\
(\%)\end{array}$ & $\begin{array}{c}{[20,49]} \\
(\%)\end{array}$ & $\begin{array}{c}{[50,99]} \\
(\%)\end{array}$ & $\begin{array}{c}{[100,199]} \\
(\%)\end{array}$ & $\begin{array}{c}>=200 \\
(\%)\end{array}$ & $\begin{array}{c}\text { Total } \\
\text { number of } \\
\text { firms }\end{array}$ \\
\hline FAMEX firms & 10 & 9 & 29 & 19 & 17 & 16 & 392 \\
Control firms & 5 & 12 & 31 & 23 & 17 & 12 & 2,319 \\
\hline
\end{tabular}

Source: Authors' calculations based on the combined dataset.

Descriptive statistics in terms of key variables used for the econometric analysis (described in Section 4) are given for all firms in the sample in Table 3.

Table 3: Summary statistics on key variables

\begin{tabular}{lcccc}
\hline & \multicolumn{2}{c}{ FAMEX firms } & \multicolumn{2}{c}{ Control firms } \\
& Average & Std. deviation & Average & Std. deviation \\
\hline Total exports (in '000s of Tunisian dinars) & 3,022 & 9,104 & 2,706 & 9,671 \\
Number of products & 3.578 & 4.666 & 1.756 & 2.881 \\
Number of destinations & 5.333 & 9.371 & 3.467 & 5.879 \\
Age & 18.243 & 9.580 & 18.451 & 11.038 \\
Dummy for 100\% exporter & 0.343 & 0.475 & 0.474 & 0.499 \\
Lagged share of exports to high-income destinations & 0.473 & 0.467 & 0.502 & 0.484 \\
Lagged average distance to export destinations & 5.256 & 3.123 & 4.822 & 3.307 \\
Lagged share of exports to MENA countries & 0.223 & 0.376 & 0.143 & 0.328 \\
Lagged shares of exports HS 1-digit 0 sector & 0.010 & 0.099 & 0.000 & 0.000 \\
Lagged shares of exports HS 1-digit 1 sector & 0.050 & 0.212 & 0.021 & 0.137 \\
Lagged shares of exports HS 1-digit 2 sector & 0.029 & 0.161 & 0.035 & 0.175 \\
Lagged shares of exports HS 1-digit 3 sector & 0.090 & 0.273 & 0.068 & 0.242 \\
Lagged shares of exports HS 1-digit 4 sector & 0.073 & 0.250 & 0.044 & 0.198 \\
Lagged shares of exports HS 1-digit 5 sector & 0.024 & 0.145 & 0.020 & 0.133 \\
Lagged shares of exports HS 1-digit 6 sector & 0.271 & 0.438 & 0.309 & 0.457 \\
Lagged shares of exports HS 1-digit 7 sector & 0.050 & 0.200 & 0.045 & 0.195 \\
Lagged shares of exports HS 1-digit 8 sector & 0.102 & 0.283 & 0.109 & 0.302 \\
Lagged average unit value by HS 6-digit relative to sample average & 0.691 & 0.761 & 0.639 & 0.877 \\
Observations & 1,500 & 1,500 & 17,305 & 17,305 \\
\hline
\end{tabular}

Notes: The summary statistics shown are based on the estimating sample that is used in the propensity score weighted regressions which estimate the effect of FAMEX in the year of treatment (column (1) of Table 8). The variables listed are defined in Section 4. 


\section{Estimation issues}

The main identification problem in evaluating the impact of FAMEX on firm-level export outcomes is that program assignment is non-random. FAMEX beneficiaries may, therefore, differ from other firms in characteristics that affect both participation decisions and outcomes. Selection bias could affect the estimated effects of FAMEX in several ways, with the direction of the bias a priori unknown. First, permanent, unobservable firm characteristics could affect both performance and the probability of treatment. For instance, better managers may be more adept at identifying both business opportunities and opportunities for outside assistance. Second, time-varying, unobservable shocks to firms could also affect both performance and the probability of treatment. For example, a temporary sales slump in the pre-treatment year may also be one of the motivations for firms to seek FAMEX assistance, as in van Biesebroeck, Yu and Chen (forthcoming); failure to correct for this could produce over-estimated FAMEX treatment effects by attributing the slump's recovery to the treatment. Alternatively, firms may have enjoyed a boom year making them optimistic about expansion and motivating them to seek out assistance to expand. If the pretreatment boom was followed by a mean-reverting slump in the treatment year, the treatment effect would be underestimated.

Given these potential issues, OLS estimation of the impact of FAMEX risks producing biased estimates. This classical problem of quasi-experimental (QE) methods - the fundamental problem of causal inference defined by Holland (1986) - requires estimation approaches that control for selection bias. The standard approach is the difference-in-differences (DID) estimator combined with propensity-score matching (PSM-DID) proposed by Heckman, Ichimura, and Todd (1997), which has been widely used in the evaluation of export promotion (Görg, Henry and Strobl, 2008; Volpe and Carballo, 2008). PSM-DID controls for selection bias by comparing the change in the program beneficiaries' performance with that of 'observationally similar' control firms. It is based on the twin assumptions that (i) assignment to treatment (or the decision to undertake it) is independent of potential outcomes, conditional on observed pre-treatment covariates (Hirano, Imbens, and Ridder, 2003); and (ii) there is sufficient overlap in the distribution of propensity scores between the treatment and control groups to find matches for all or most treated firms. By relying on a comparison of changes in an outcome, the PSM-DID estimator also controls for unobserved time-invariant pre-program differences across firms, which could lead to self-selection into the program and influence outcomes (Blundell and Costa Dias, 2009).

A PSM algorithm matches each treated firm with the 'most similar' control firms, i.e., those with the closest propensity score, the latter being obtained from a regression of treatment status in any sample year on a set of firm characteristics likely to correlate with selection into the program. 
While Glazerman, Levy, and Myers (2003) show that PSM successfully reduces selection bias in impact evaluation, particularly when combined with DID or, as we will see below, propensity score weighted regression, these approaches have well-known limitations. In particular, estimates may still be biased if unobserved time-varying firm characteristics affect both participation and outcomes. While there is no perfect fix, we deal with these issues through two complementary approaches. First, we control for permanent differences in export performance across firms with firm fixed effects. Second, we control for pre-treatment performance (boom or bust) by matching on the basis of lagged export performance. As we will see in Section 5, matching leads to a drastic reduction in estimated treatment effects compared to OLS.

Let us now describe our approach in detail. Our treatment status variable must fulfill three specific requirements. First, it must take into account that FAMEX was provided to different firms in different years. Second, it must allow us to estimate the persistence of FAMEX treatment effects beyond the treatment year. Finally, it must prevent the PSM algorithm from matching a treated firm with either itself or another treated firm after the treatment is over, in essence considering treated firms after treatment as controls.

Let $T$ be the set of treated firms and $C$ the set of control firms. Indexing firms by $i$ and years by $t$, let $y_{i t}$ be a performance outcome variable (we will use alternatively total exports, the number of destinations, and the number of products), and $t(i)$ the year in which firm $i$ received the one-year FAMEX program. Our approach is to compare a firm's performance at $t(i)+k$ with a counterfactual made of (i) its own performance in the three years before treatment for which data is available for all firms and (ii) that of control firms over the same period. For this, we define a sequence of treatment status variables $D_{i t}^{k}$, each used in a separate regression and equal to one only at $t(i)+k$, with $k=0$ measuring the impact effect, $k=1$ measuring the one-year-after effects, and so on until $k=5$. For instance, for a firm treated in $2005, D_{i t}^{0}$ compares its performance in 2005 with that in 2002-2004 and with that of control firms over the same period; while $D_{i t}^{1}$ compares its performance in 2006 with that in 2002-2004 and with that of control firms over the same period. Regarding the last requirement, we code $D_{i t}^{k}$ as missing in all years beyond $t(i)+k$. Thus, letting a period "." stand for a missing value, we have: 


$$
D_{i t}^{k}=\left\{\begin{array}{cc}
1 & \text { if } i \in T \text { and } t=t(i)+k, \quad k=0, \ldots, 5 \\
0 & \text { if } i \in C \text { or }[i \in T \text { and } t(i)-3 \leq t \leq t(i)-1] \\
. & \text { otherwise. }
\end{array}\right.
$$

The resulting structure of the treatment status variables for a treated firm is shown in Table 4, with "analytical time" (time relative to firm $i$ 's treatment year $t(i)$ ) shown in rows and $k$ in columns.

Table 4: Structure of the treatment status variables

\begin{tabular}{lcccccc}
\hline & $k=0$ & $k=1$ & $k=2$ & $k=3$ & $k=4$ & $k=5$ \\
\hline$t(i)-3$ & 0 & 0 & 0 & 0 & 0 & 0 \\
$t(i)-2$ & 0 & 0 & 0 & 0 & 0 & 0 \\
$t(i)-1$ & 0 & 0 & 0 & 0 & 0 & 0 \\
$t(i)$ & 1 &. &. &. &. &. \\
$t(i)+1$ &. & 1 &. &. &. &. \\
$t(i)+2$ &. &. & 1 &. &. &. \\
$t(i)+3$ &. &. &. & 1 &. & $\cdot$ \\
$t(i)+4$ &. &. &. &. & 1 &. \\
$t(i)+5$ &. &. &. &. &. & 1 \\
\hline
\end{tabular}

Note: a dot indicates the years when the treatment status variable is coded as missing; $t(i)$ indicates firm $i$ 's treatment year.

The first-stage probit regression uses $D_{i t}^{0}$ as its dependent variable (treatment status at $t$ ) and is given by:

$$
\operatorname{Pr}\left(D_{i t}^{0}=1\right)=f\left(\mathbf{X}_{i t} \boldsymbol{\alpha}+\delta_{s(i), t}+v_{i t}\right)
$$

where $\mathbf{X}_{i t}$ is a vector of firm covariates and $\delta_{s(i), t}$ is a vector of sector-year fixed effects, $s(i)$ being firm $i$ 's sector. ${ }^{18}$ We include in $\mathbf{X}_{i t}$ one-year lagged growth in all three outcome variables (total exports, number of destinations, and number of products), firm age and its square, a categorical variable (size bins) for firm employment, a dummy variable identifying whether the firm exports 100 percent of its output, one-year lagged export shares to high-income destinations and to Middle East and North Africa (MENA) countries, lagged average distance to export destinations, lagged export shares by HS section, lagged average unit value by HS 6-digit (relative to the sample average), as well as location fixed effects. ${ }^{19}$ Formally, letting $c$ index destination

\footnotetext{
18 The sector-year fixed effects are based on the seven sectors shown in Panel A of Table 2. Given the importance of accounting for sector-year fixed effects, the sample used for the probit regression estimation does not include the pre-treatment years for FAMEX firms nor the years 2002-2004 for control firms. Since no firm is treated in 2002-2004, the dependent variable in the probit is 0 for all observations in those years and hence data for those years cannot be included in the probit with sector-year fixed effects.

${ }^{19}$ Lagged growth in performance measures is included in order to control for selection on the basis of pre-treatment growth. We are grateful to a referee for attracting our attention to this issue. Similar results were obtained controlling for 2-, 3- or 4-year lagged growth in outcomes. We chose to use one-year lagged growth so as to keep the largest possible number of FAMEX firms in the sample given that the longer is the time difference used in calculating lagged growth, the longer it requires FAMEX firms to have been exporting consecutively for more years prior to the program. High-income destinations are defined according to the World
} 
countries, $w_{i c, t-1}$ be the share of destination $c$ in firm $i$ 's total exports in year $t-1$, and $d_{c}$ the distance to destination $c$ taken from the CEPII database, the lagged average distance to export destinations is given by:

$$
d_{i, t-1}=\sum_{c} w_{i c, t-1} \ln \left(d_{c}\right)
$$

and the lagged relative unit value is given by:

$$
p_{i, t-1}=\sum_{k} w_{i k, t-1}\left(p_{i k, t-1} / \bar{p}_{k, t-1}\right)
$$

where $p_{i k, t-1}$ is the unit value of HS 6-digit product $k$ when exported by firm $i$ at $t-1, \bar{p}_{k, t-1}$ is the average unit value of product $k$ over all firms in the sample exporting it at $t-1$, and $w_{i k, t-1}$ is the share of product $k$ in firm $i$ 's total exports at $t-1$.

For the treatment effect equation, a complication arises in our setup because the treatment year $t(i)$ is undefined for control firms. In standard statistical packages for propensity score matching estimation (such as psmatch2 in STATA), treated firms are matched with control ones in any year, which may be problematic if calendar time matters for performance as is the case in our sample period. We address this issue by using the propensity score weighted regression method henceforth designated as PS weighted regression method - proposed by Hirano, Imbens, and Ridder (2003) - henceforth designated as HIR. HIR show that the estimator of the average treatment effect obtained by that method is actually more efficient than the PSM-DID estimator. ${ }^{20}$ The HIR method uses the estimated propensity scores obtained from the first-stage probit regression to construct weights for the observations used for a treatment effect regression focusing on treated and control firms in the common support. Letting $\hat{p}_{i t}$ be the estimated propensity score of firm $i$ (treated or control) at $t$ and $\hat{r}_{i t}=\hat{p}_{i t} /\left(1-\hat{p}_{i t}\right)$ its estimated odds, the HIR's regressionweighing scheme is given by:

$$
\omega_{i t}=\left\{\begin{array}{cc}
1 & \text { if } i \in T \\
\hat{r}_{i t} & \text { if } i \in C .
\end{array}\right.
$$

Bank country income classification. Export shares by HS section are defined as the shares of each firm's total exports by HS 1digit sector (given that each firm can export in more than one different HS 1-digit sector).

${ }^{20}$ See DiNardo, Fortin, and Lemieux (1996), Van de Walle and Mu (2007), and Chen, Mu, and Ravallion (2009) for applications of the method. 
That is, the scheme assigns a unit weight to each treated firm and a weight equal to $\hat{r}_{i t}$ to each control firm, weighing more heavily those firms with a higher propensity score (the more "treatable" firms among the control group). The advantage of a regression framework is its flexibility in including covariates and control variables, in particular calendar-year fixed effects which matter for us given that our sample period includes large macroeconomic swings.

Our baseline treatment effect equation is the PS weighted regression given below estimated using the weights defined by Eq. (5):

$$
y_{i t}=\beta D_{i t}^{k}+\mathbf{X}_{i t} \gamma+\delta_{i}+\delta_{s(i), t}+u_{i t}, \quad k=0, \ldots, 5
$$

where $y_{i t}$ is alternatively the log of total exports, of the number of destinations, or of the number of products, and $\mathbf{X}_{i t}$ is a vector of firm covariates including the first-stage probit regression's explanatory variables (except lagged growth in performance). Importantly, Eq. (6) includes firm fixed effects $\delta_{i}$ that control for unobservable firm heterogeneity and sector-year fixed effects

$\delta_{s(i), t}$ that control for sectoral time-varying demand or technology shocks. Note that as $k$ rises, sample size shrinks mechanically, as firms treated in 2009 have no observation beyond $k=1$, firms treated in 2008 have no observation beyond $k=2$, and so on. For robustness, we have estimated Eq. (6) on a sample including only firms treated in 2005 (along with all control firms) for which coefficients for all $k$ are possible to obtain; the corresponding results are shown in Section 6 and are very similar to the baseline results reported in Section 5.3.

\section{Baseline results}

In this section, we first present OLS estimates of the FAMEX treatment effect as a benchmark. We then move on to our main approach, which involves probit estimates of FAMEX participation and propensity score weighted regression estimates. Finally, we examine heterogeneity in treatment effects.

\subsection{OLS estimates}

Before implementing the PS weighted regression method just described, we present in Table 5 the result of estimating Eq. (6) by OLS with firm fixed effects but no weights, i.e., ignoring the matching. Each cell with a coefficient, a standard error and an R-square corresponds to a distinct regression, with coefficients on control variables not reported for brevity. The first column reports 
the impact effect, the second column reports the effect one year after treatment, and so on. FAMEX's impact effect on total exports, number of destinations, and number of products is large and significant at the one percent confidence level. Moreover, the effect is persistent for all three outcomes up to five years after treatment. ${ }^{21}$ However, as we will see, these estimates are vulnerable to selection bias and likely to be largely overestimated.

\begin{tabular}{|c|c|c|c|c|c|c|}
\hline Forwarding degree & TY $(k=0)$ & $\mathrm{TY}+1(k=1)$ & $\mathrm{TY}+2(k=2)$ & $\mathrm{TY}+3(k=3)$ & $\mathrm{TY}+4(k=4)$ & $\mathrm{TY}+5(k=5)$ \\
\hline Estimator & $\begin{array}{l}\text { OLS } \\
(1)\end{array}$ & $\begin{array}{l}\text { OLS } \\
\text { (2) }\end{array}$ & $\begin{array}{l}\text { OLS } \\
\text { (3) }\end{array}$ & $\begin{array}{l}\text { OLS } \\
\text { (4) }\end{array}$ & $\begin{array}{l}\text { OLS } \\
(5)\end{array}$ & $\begin{array}{l}\text { OLS } \\
(6)\end{array}$ \\
\hline \multicolumn{7}{|l|}{ Outcome } \\
\hline Total exports & $\begin{array}{l}0.774 * * * \\
{[0.187]}\end{array}$ & $\begin{array}{l}0.890 * * * * \\
{[0.204]}\end{array}$ & $\begin{array}{l}0.445^{* * *} \\
{[0.220]}\end{array}$ & $\begin{array}{l}0.600 * * * * \\
{[0.227]}\end{array}$ & $\begin{array}{l}0.519^{*} \\
{[0.282]}\end{array}$ & $\begin{array}{l}0.852^{* * * *} \\
{[0.290]}\end{array}$ \\
\hline$R$-squared & 0.550 & 0.552 & 0.551 & 0.551 & 0.544 & 0.551 \\
\hline Nb. destinations & $\begin{array}{l}0.338 * * * * \\
{[0.033]}\end{array}$ & $\begin{array}{l}0.355^{* * * *} \\
{[0.033]}\end{array}$ & $\begin{array}{l}0.323 * * * \\
{[0.037]}\end{array}$ & $\begin{array}{l}0.288 * * * * \\
{[0.036]}\end{array}$ & $\begin{array}{l}0.305 * * * \\
{[0.043]}\end{array}$ & $\begin{array}{l}0.353^{* * * *} \\
{[0.045]}\end{array}$ \\
\hline$R$-squared & 0.413 & 0.417 & 0.416 & 0.417 & 0.412 & 0.418 \\
\hline $\mathrm{Nb}$. products & $\begin{array}{l}0.290 * * * \\
{[0.039]}\end{array}$ & $\begin{array}{l}0.285^{* * * *} \\
{[0.041]}\end{array}$ & $\begin{array}{l}0.240 * * * \\
{[0.042]}\end{array}$ & $\begin{array}{l}0.230 * * * * \\
{[0.044]}\end{array}$ & $\begin{array}{l}0.265^{* * * *} \\
{[0.054]}\end{array}$ & $\begin{array}{l}0.337 * * * * \\
{[0.053]}\end{array}$ \\
\hline$R$-squared & 0.414 & 0.415 & 0.415 & 0.414 & 0.411 & 0.416 \\
\hline Observations & 18,805 & 21,089 & 21,077 & 18,638 & 13,802 & 9,197 \\
\hline \multicolumn{7}{|c|}{ Fixed effects included in 3 regressions above } \\
\hline Firm & Yes & $\overline{\text { Yes }}$ & Yes & Yes & Yes & Yes \\
\hline Sector-year & Yes & Yes & Yes & Yes & Yes & Yes \\
\hline
\end{tabular}

Notes: robust standard errors in brackets; *: significant at 10\%; **: significant at 5\%; ***: significant at $1 \%$. The sample includes treated and control firms in the common support (although no propensity score weights are used). Each cell with a coefficient, a standard error, and an R-squared in the table corresponds to a separate regression (18 regressions in all). The other firm covariates whose coefficients are omitted for brevity are: the lagged share of firm exports to high-income destinations, the lagged share of firm exports to MENA countries, the lagged average distance to export destinations, the lagged export shares by HS section, and the lagged firm average unit value by HS 6-digit (relative to the sample average).

\subsection{First-stage probit estimates}

Next, we implement the first-stage probit estimation that generates the propensity score weights for the PS weighted regressions. Table 6 reports the first-stage probit regression estimates. ${ }^{22}$ Interestingly, although lagged growth in total exports correlates positively with treatment status in an (unreported) unconditional probit regression (i.e., a probit that includes as a regressor only lagged growth in total exports), it is no longer significant once other firm characteristics are included. Thus, FAMEX firms do not seem to have faster pre-treatment growth than control ones in the same sector-year once their characteristics are controlled for. Lagged growth in other outcomes (number of destinations and products) similarly fails to correlate with treatment status.

\footnotetext{
${ }^{21}$ The larger number of observations in column (2) than in column (1) is due to the fact that no firm is treated in 2010 and as such data for 2010 on treated and control firms is not included in the estimating sample in column (1) but is included in the estimating sample in column (2).

22 The probit regression for propensity score matching includes sector-year fixed effects but it is not possible to do the matching sector-by-sector because of the small size of sector sub-samples.
} 
As for other firm characteristics, the probability of treatment correlates negatively with being an exporter-only firm, indicating that the program targeted firms with more limited participation in exports. The treatment probability is lower for all size bins other than the smallest (fewer than 10 workers, the omitted bin) and for all locations other than Tunis (the omitted location), but rises with the average distance to export destinations. Unreported sector-year dummies are all insignificant, suggesting no sectoral targeting.

Table 6: First-stage probit results for FAMEX treatment status

\begin{tabular}{|c|c|c|c|}
\hline \multirow{2}{*}{$\begin{array}{l}\begin{array}{l}\text { Dep. variable } \\
\text { Estimator }\end{array} \\
\underline{\text { Regressors }}\end{array}$} & \multicolumn{3}{|l|}{$\begin{array}{l}\text { FAMEX treatment status } \\
\text { Probit }\end{array}$} \\
\hline & & Regressors (cont'd) & \\
\hline Lagged growth in total exports & $\begin{array}{c}-0.014 \\
{[0.011]}\end{array}$ & $\begin{array}{l}\text { Lagged avg. unit value by HS 6- } \\
\text { digit relative to sample avg. }\end{array}$ & $\begin{array}{c}0.020 \\
{[0.023]}\end{array}$ \\
\hline Lagged growth in nb. destinations & 0.060 & $\underline{\text { Size-bin categories }}$ & \\
\hline & [0.104] & 10-19 employees & $-0.542 * * *$ \\
\hline Lagged growth in nb. products & $\begin{array}{c}0.031 \\
{[0.063]}\end{array}$ & 20-49 employees & $\begin{array}{c}{[0.122]} \\
-0.383^{* * * *}\end{array}$ \\
\hline Age $(\log )$ & 0.449 & & [0.099] \\
\hline & [0.379] & 50-99 employees & $-0.376^{* * * *}$ \\
\hline Age squared $(\log )$ & $\begin{array}{l}-0.115^{*} \\
{[0.067]}\end{array}$ & 100-199 employees & $\begin{array}{c}{[0.107]} \\
-0.315^{* * *}\end{array}$ \\
\hline $100 \%$ exporter & $-0.333 * * *$ & & [0.111] \\
\hline Lagged share of exports to high- & {$[0.081]$} & More than 200 employees & $\begin{array}{l}-0.198^{*} \\
{[0.114]}\end{array}$ \\
\hline income destinations & $\begin{array}{c}-0.099 \\
{[0.111]}\end{array}$ & Location fixed effects & \\
\hline Lagged share of exports to & & & \\
\hline MENA countries & $\begin{array}{c}0.046 \\
{[0.110]}\end{array}$ & Grand Tunis & $\begin{array}{c}-0.359 * * * \\
{[0.074]}\end{array}$ \\
\hline $\begin{array}{l}\text { Lagged average distance to } \\
\text { export destinations }\end{array}$ & $\begin{array}{c}0.069 * * * \\
{[0.021]}\end{array}$ & Central Sea & $\begin{array}{c}-0.966 * * * * \\
{[0.164]}\end{array}$ \\
\hline & & Rest of Tunisia & $\begin{array}{c}-0.487^{* * * *} \\
{[0.079]}\end{array}$ \\
\hline Sector-year fixed effects & Yes & & \\
\hline
\end{tabular}

Notes: robust standard errors in brackets; *: significant at 10\%; **: significant at 5\%; ***: significant at $1 \%$. Additionally, the probit regression includes the firm-level lagged share of exports by HS section. The omitted location is Tunis and the omitted size bin is less than 10 workers. Lagged growth in total exports, number of destinations and number of products is measured in the pretreatment year (TY-1) for FAMEX firms and in any year for control firms.

The distributions of propensity scores for the treatment and control groups have a large common support, which includes 392 FAMEX beneficiaries and 2,319 control firms. ${ }^{23}$ Following Rosenbaum and Rubin (1983), Dehejia and Wahba (2002), and Smith and Todd (2005), we run standard balancing tests to assess whether matching corrects for significant differences in the distribution of pre-treatment covariates between the treatment and control groups. Results are reported in Table 7 for the key firm covariates and suggest that differences in pre-treatment

\footnotetext{
${ }^{23}$ The distributions of propensity scores (available in the online appendix) are also fairly similar in shape, although not completely overlapping, highlighting the importance of matching. The importance of a large common support and similarity in the distribution of covariates/propensity scores across treated and control groups for unbiased PSM-DID estimators is discussed by Heckman, Ishimura and Todd (1997).
} 
covariates are largely eliminated by matching. In particular, the average pre-treatment growth in total exports is much higher, before matching, for treated firms at 65.2 percent than for untreated ones at 8.4 percent; however, matching assigns, in each year, a greater weight to control firms with high growth in the previous year, raising the matched control group's lagged growth in total exports to 59.2 percent which is close and statistically similar to the pre-treatment average for FAMEX firms in the common support of 67 percent.

Table 7 : Balancing test results for determinants of FAMEX treatment status

\begin{tabular}{|c|c|c|c|c|c|c|c|}
\hline & & & & Standardized & Percentage & & \\
\hline & & Treated & Control & bias & $\begin{array}{c}\text { reduction } \\
\text { in standardized } \\
\text { bias } \\
\end{array}$ & T-statistic & P-value \\
\hline Lagged growth in total exports & Unmatched & 0.652 & 0.084 & 13.8 & & 2.62 & 0.009 \\
\hline & Matched & 0.670 & 0.592 & 1.9 & 86.4 & 0.26 & 0.791 \\
\hline Lagged growth in nb. destinations & Unmatched & 0.076 & 0.009 & 14.1 & & 3.12 & 0.002 \\
\hline & Matched & 0.082 & 0.073 & 2 & 86 & 0.27 & 0.788 \\
\hline Lagged growth in nb. products & Unmatched & 0.086 & 0.009 & 12.6 & & 2.61 & 0.009 \\
\hline & Matched & 0.090 & 0.088 & 0.4 & 96.9 & 0.05 & 0.957 \\
\hline Age $(\log )$ & Unmatched & 2.714 & 2.638 & 12.6 & & 2.4 & 0.017 \\
\hline & Matched & 2.744 & 2.733 & 1.9 & 84.7 & 0.3 & 0.767 \\
\hline Age squared (log) & Unmatched & 7.690 & 7.361 & 10.3 & & 1.98 & 0.048 \\
\hline & Matched & 7.824 & 7.765 & 1.8 & 82.2 & 0.27 & 0.785 \\
\hline $100 \%$ exporter & Unmatched & 1.345 & 1.487 & -29.1 & & -5.65 & 0.000 \\
\hline & Matched & 1.346 & 1.358 & -2.5 & 91.4 & -0.36 & 0.721 \\
\hline Lagged share of exports to high-income destinations & Unmatched & 0.500 & 0.505 & -1 & & -0.2 & 0.841 \\
\hline & Matched & 0.510 & 0.496 & 2.9 & -184.1 & 0.41 & 0.680 \\
\hline Lagged share of exports to MENA countries & Unmatched & 0.240 & 0.148 & 25.4 & & 5.46 & 0.000 \\
\hline & Matched & 0.240 & 0.229 & 3.1 & 87.9 & 0.4 & 0.690 \\
\hline Lagged average distance to export destinations & Unmatched & 5.656 & 4.930 & 23.5 & & 4.43 & 0.000 \\
\hline & Matched & 5.724 & 5.530 & 6.3 & 73.3 & 0.94 & 0.350 \\
\hline Lagged avg. unit value by HS 6-digit relative to sample avg. & Unmatched & 0.747 & 0.655 & 10.2 & & 1.73 & 0.084 \\
\hline & Matched & 0.758 & 0.725 & 3.6 & 64.1 & 0.56 & 0.575 \\
\hline 10-19 employees & Unmatched & 0.096 & 0.132 & -11.1 & & -2.08 & 0.037 \\
\hline & Matched & 0.087 & 0.100 & -3.9 & 64.9 & -0.59 & 0.553 \\
\hline 20-49 employees & Unmatched & 0.284 & 0.297 & -2.9 & & -0.58 & 0.564 \\
\hline & Matched & 0.287 & 0.291 & -0.8 & 74.1 & -0.11 & 0.916 \\
\hline 50-99 employees & Unmatched & 0.195 & 0.218 & -5.6 & & -1.09 & 0.274 \\
\hline & Matched & 0.192 & 0.189 & 0.9 & 84.8 & 0.12 & 0.902 \\
\hline 100-199 employees & Unmatched & 0.160 & 0.162 & -0.4 & & -0.09 & 0.931 \\
\hline & Matched & 0.167 & 0.168 & -0.4 & 13.3 & -0.05 & 0.959 \\
\hline More than 200 employees & Unmatched & 0.156 & 0.110 & 13.5 & & 2.89 & 0.004 \\
\hline & Matched & 0.162 & 0.149 & 3.7 & 72.3 & 0.49 & 0.626 \\
\hline Grand Tunis & Unmatched & 0.473 & 0.449 & 4.8 & & 0.95 & 0.342 \\
\hline & Matched & 0.477 & 0.462 & 2.9 & 38.1 & 0.41 & 0.681 \\
\hline Central Sea & Unmatched & 0.020 & 0.076 & -26.7 & & -4.28 & 0.000 \\
\hline & Matched & 0.021 & 0.034 & -6.4 & 76.0 & -1.16 & 0.245 \\
\hline Rest of Tunisia & Unmatched & 0.283 & 0.368 & -18.2 & & -3.51 & 0.000 \\
\hline & Matched & 0.285 & 0.292 & -1.6 & 91.4 & -0.23 & 0.822 \\
\hline
\end{tabular}

\subsection{PS weighted regression estimates}


Table 8 shows the PS weighted regression estimates for all three firm-level outcomes: (i) total exports (in Tunisian dinars), (ii) the number of export destinations, and (iii) the number of export products, all in log-levels. The first column shows a large and significant positive impact effect of FAMEX on total exports (an additional 51 percent relative to control firms) and, to a lesser extent, on the number of destinations served (11 percent) and number of products ( 9 percent). ${ }^{24}$ The second column shows that the FAMEX effect is still there, and in fact slightly higher, at TY+1. However, by TY+2, only a slight effect on the number of destinations lingers on. In terms of total exports and number of products, treated firms are back on par with the control group. Three years after the intervention, beneficiaries' total exports and diversification are no longer significantly different from those of control firms. The erosion of treatment effects over time comes from a combination of lower point estimates and larger standard errors as one moves from left to right across Table 8, suggesting that it reflects not just censoring effects (as the number of firms with data shrinks, by construction, toward the end of the sample period) but genuinely vanishing treatment effects, especially for total exports. ${ }^{25}$

\begin{tabular}{|c|c|c|c|c|c|c|}
\hline $\begin{array}{l}\text { orwarding degree } \\
\text { Estimator }\end{array}$ & $\begin{array}{l}\text { TY }(k=0) \\
\text { PS weighted } \\
\text { (1) }\end{array}$ & $\begin{array}{l}\text { TY+1 }(k=1) \\
\text { PS weighted } \\
\text { (2) }\end{array}$ & $\begin{array}{l}\text { TY+2 }(k=2) \\
\text { PS weighted } \\
\text { (3) }\end{array}$ & $\begin{array}{l}\text { TY+3 }(k=3) \\
\text { PS weighted } \\
\text { (4) }\end{array}$ & $\begin{array}{l}\text { TY+4 }(k=4) \\
\text { PS weighted } \\
\text { (5) }\end{array}$ & $\begin{array}{l}\text { TY+5 }(k=5) \\
\text { PS weighted } \\
\text { (6) }\end{array}$ \\
\hline \multicolumn{7}{|l|}{ Dutcome } \\
\hline Total exports & $\begin{array}{l}0.411^{* *} \\
{[0.171]}\end{array}$ & $\begin{array}{l}0.486^{* *} \\
{[0.200]}\end{array}$ & $\begin{array}{l}0.208 \\
{[0.216]}\end{array}$ & $\begin{array}{l}0.080 \\
{[0.280]}\end{array}$ & $\begin{array}{l}0.009 \\
{[0.349]}\end{array}$ & $\begin{array}{l}0.144 \\
{[0.327]}\end{array}$ \\
\hline$R$-squared & 0.793 & 0.770 & 0.765 & 0.762 & 0.746 & 0.740 \\
\hline $\mathrm{Nb}$. destinations & $\begin{array}{l}0.104^{* * * *} \\
{[0.022]}\end{array}$ & $\begin{array}{l}0.111 * * * \\
{[0.027]}\end{array}$ & $\begin{array}{l}0.076^{* *} \\
{[0.032]}\end{array}$ & $\begin{array}{l}0.022 \\
{[0.033]}\end{array}$ & $\begin{array}{l}-0.014 \\
{[0.046]}\end{array}$ & $\begin{array}{l}0.039 \\
{[0.045]}\end{array}$ \\
\hline$R$-squared & 0.840 & 0.825 & 0.813 & 0.807 & 0.787 & 0.783 \\
\hline $\mathrm{Nb}$. products & $\begin{array}{l}0.086^{* * * *} \\
{[0.031]}\end{array}$ & $\begin{array}{l}0.081^{* *} \\
{[0.037]}\end{array}$ & $\begin{array}{l}0.062 \\
{[0.042]}\end{array}$ & $\begin{array}{l}-0.025 \\
{[0.047]}\end{array}$ & $\begin{array}{l}-0.009 \\
{[0.053]}\end{array}$ & $\begin{array}{l}0.072 \\
{[0.055]}\end{array}$ \\
\hline$R$-squared & 0.799 & 0.783 & 0.773 & 0.761 & 0.755 & 0.755 \\
\hline $\begin{array}{l}\text { Dbservations } \\
\text { Eixed effects includ }\end{array}$ & $\begin{array}{l}18,805 \\
\text { in } 3 \text { regressior }\end{array}$ & $\begin{array}{l}21,089 \\
\text { bove }\end{array}$ & 21,077 & 18,638 & 13,802 & 9,197 \\
\hline Firm & Yes & $\overline{\text { Yes }}$ & Yes & Yes & Yes & Yes \\
\hline Sector-year & Yes & Yes & Yes & Yes & Yes & Yes \\
\hline
\end{tabular}

Notes: robust standard errors in brackets; *: significant at 10\%; **: significant at 5\%; ***: significant at $1 \%$. The sample includes treated and control firms in the common support. Each cell with a coefficient, a standard error, and an R-squared in the table corresponds to a separate regression (18 regressions in all). The other firm covariates whose coefficients are omitted for brevity are: the lagged share of exports to high-income destinations, the lagged share of exports to MENA countries, the lagged average distance to export destinations, the lagged export shares by HS section, and the lagged average unit value by HS 6-digit relative to the sample average.

\footnotetext{
${ }^{24}$ The figure of 51 percent corresponds to $\exp (0.411)-1$. More generally, the effects are calculated as $e^{\beta}-1$ (with $\beta$ being the estimate in Table 8), which measures the increment to the dependent variable in log-levels from the binary treatment status regressor.

${ }^{25}$ One way of isolating the relative importance of declining point estimates and increasing standard errors, is to fix standard errors at their lowest level, i.e. the level estimated in the treatment year when all firms are still in the sample. Even with such a hypothetical standard error, treatment effects on total exports are never significant in later years. However, treatment effects for the number of destinations in TY +5 are significant at the 10 percent confidence level and for the number of products in TY +3 and TY +5 at the 5 percent confidence level.
} 


\subsection{Heterogeneity in treatment effects}

A natural question is whether firm heterogeneity affects treatment effects and their durability. A vast theoretical and empirical literature relates the ability to export successfully with firm size; based on this, we first interact treatment status with size based on three employment bins (less than 20, 20 to 99, and more than 100 employees), with results shown in Table 9. There is indeed heterogeneity, but across firm sizes either there are no positive effects or the positive effects are temporary. For total exports, the strongest treatment effects are for medium-sized firms (with 20 to 99 employees) but these last only for two periods. The firms in this size category are, by most countries' standards, small exporters. Given the dominance of large exporters in total exports in all countries (see Freund and Pierola, forthcoming), the absence of impact on firms with more than 100 employees suggests that the program's impact may be too small to make a durable difference in Tunisia's aggregate export performance (in contrast with the results reported by the crosscountry literature by Lederman, Olarreaga and Payton (2010)). The picture is slightly different in terms of number of destinations served, as large firms (with more than 100 employees) have the largest treatment effect, though still lasting only three years. For those firms, it seems that FAMEX did help to break into new markets for a certain period, but possibly at an experimental or pilotstage scale too small to be sustained or to make a significant difference to their total exports. 
Table 9: FAMEX treatment effects by size bin estimated by PS weighted regression

\begin{tabular}{|c|c|c|c|c|c|c|c|}
\hline \multicolumn{2}{|l|}{ Forwarding degree } & \multirow{2}{*}{$\begin{array}{l}\text { TY }(k=0) \\
\text { PS weighted } \\
\text { (1) }\end{array}$} & \multirow{2}{*}{$\begin{array}{l}\text { TY }+1(k=1) \\
\text { PS weighted } \\
\text { (2) }\end{array}$} & \multirow{2}{*}{$\begin{array}{l}\text { TY }+2(k=2) \\
\text { PS weighted } \\
\text { (3) }\end{array}$} & \multirow{2}{*}{$\begin{array}{l}\text { TY }+3(k=3) \\
\text { PS weighted } \\
\text { (4) }\end{array}$} & \multirow{2}{*}{$\begin{array}{l}\text { TY }+4(k=4 \\
\text { PS weighted } \\
\text { (5) }\end{array}$} & \multirow{2}{*}{$\begin{array}{l}\text { TY }+5(k=5) \\
\text { PS weighted } \\
(6)\end{array}$} \\
\hline & & & & & & & \\
\hline \multicolumn{8}{|l|}{ Outcome } \\
\hline \multirow[t]{6}{*}{ Total exports } & Treatment*Small & 0.141 & 0.132 & $-1.248 * *$ & -0.714 & $-1.463^{*}$ & -1.387 \\
\hline & & {$[0.622]$} & {$[0.546]$} & {$[0.585]$} & {$[0.711]$} & {$[0.810]$} & {$[1.182]$} \\
\hline & Treatment*Medium & $0.481 * *$ & $0.764 * * *$ & 0.396 & 0.059 & 0.246 & 0.481 \\
\hline & & {$[0.232]$} & {$[0.258]$} & {$[0.271]$} & {$[0.340]$} & {$[0.413]$} & {$[0.443]$} \\
\hline & Treatment*Large & $0.376^{*}$ & 0.107 & 0.375 & 0.443 & -0.072 & -0.009 \\
\hline & & {$[0.198]$} & {$[0.269]$} & {$[0.306]$} & {$[0.371]$} & {$[0.488]$} & {$[0.447]$} \\
\hline$R$-squared & & 0.794 & 0.770 & 0.766 & 0.763 & 0.746 & 0.741 \\
\hline \multirow[t]{6}{*}{$\mathrm{Nb}$. destinations } & Treatment*Small & 0.054 & $0.145^{*}$ & 0.004 & -0.015 & $-0.199 * *$ & $-0.210^{*}$ \\
\hline & & {$[0.068]$} & {$[0.075]$} & {$[0.089]$} & {$[0.084]$} & {$[0.096]$} & {$[0.110]$} \\
\hline & Treatment*Medium & $0.100^{* * * *}$ & $0.097^{* * * *}$ & 0.048 & 0.010 & -0.015 & 0.049 \\
\hline & & [0.029] & {$[0.032]$} & {$[0.037]$} & {$[0.041]$} & {$[0.055]$} & {$[0.058]$} \\
\hline & Treatment*Large & $0.128 * * *$ & $0.124 * * *$ & $0.148^{* * * *}$ & 0.063 & 0.029 & 0.079 \\
\hline & & {$[0.036]$} & {$[0.042]$} & {$[0.049]$} & {$[0.051]$} & {$[0.073]$} & {$[0.074]$} \\
\hline$R$-squared & & 0.840 & 0.825 & 0.814 & 0.807 & 0.788 & 0.784 \\
\hline \multirow[t]{6}{*}{$\mathrm{Nb}$. products } & Treatment*Small & 0.091 & 0.076 & -0.070 & -0.123 & $-0.347^{* *}$ & $-0.356^{* *}$ \\
\hline & & [0.112] & [0.094] & {$[0.112]$} & [0.113] & {$[0.147]$} & {$[0.173]$} \\
\hline & Treatment*Medium & $0.103^{* * * *}$ & $0.095^{\text {** }}$ & 0.075 & 0.004 & 0.024 & 0.116 \\
\hline & & {$[0.040]$} & {$[0.045]$} & {$[0.050]$} & [0.059] & [0.064] & {$[0.072]$} \\
\hline & Treatment*Large & 0.054 & 0.058 & 0.084 & -0.043 & 0.012 & 0.102 \\
\hline & & {$[0.047]$} & {$[0.058]$} & {$[0.062]$} & {$[0.071]$} & {$[0.086]$} & {$[0.086]$} \\
\hline \multicolumn{2}{|l|}{$R$-squared } & 0.799 & 0.783 & 0.774 & 0.761 & 0.756 & 0.757 \\
\hline Observations & & 18,805 & 21,089 & 21,077 & 18,638 & 13,802 & 9,197 \\
\hline \multicolumn{8}{|c|}{ Fixed effects included in 3 regressions above } \\
\hline \multirow{2}{*}{\multicolumn{2}{|c|}{$\begin{array}{l}\text { Firm } \\
\text { Sector-year }\end{array}$}} & $\overline{\text { Yes }}$ & Yes & Yes & Yes & Yes & Yes \\
\hline & & Yes & Yes & Yes & Yes & Yes & Yes \\
\hline
\end{tabular}

Notes: robust standard errors in brackets; *: significant at 10\%; **: significant at 5\%; ***: significant at 1\%. Small means firms with fewer than 20 employees, medium means firms between 20 and 99 employees, and large means firms with 100 or more employees. Each cell with 3 coefficients, 3 standard errors, and an R-squared in the table corresponds to a separate regression (18 regressions in all). The other firm covariates whose coefficients are omitted for brevity are: the lagged share of exports to highincome destinations, the lagged share of exports to MENA countries, the lagged average distance to export destinations, the lagged export shares by HS section, and the lagged average unit value by HS 6-digit relative to the sample average.

Next, we interact the treatment variable with a direct proxy for "export-readiness", namely a dummy variable indicating whether the beneficiary firm had an export cell at the start of the treatment. Results are shown in Table 10. The strongest treatment effects, albeit still temporary, appear on firms with no prior export cell, i.e., the firms with the least degree of "export-readiness," suggesting that the contribution of FAMEX was fairly basic and provided little additional benefit to firms that were already better equipped to export. 
Table 10: FAMEX treatment effects and export-readiness estimated by PS weighted regression

\begin{tabular}{|c|c|c|c|c|c|c|c|}
\hline \multicolumn{2}{|l|}{ Forwarding degree } & $\mathrm{TY}(k=0)$ & $\mathrm{TY}+1(k=1)$ & $\mathrm{TY}+2(k=2)$ & $\mathrm{TY}+3(k=3)$ & $\mathrm{TY}+4(k=4)$ & $\mathrm{TY}+5(k=5)$ \\
\hline \multicolumn{2}{|l|}{ Estimator } & $\begin{array}{l}\text { PS weighted } \\
\text { (1) }\end{array}$ & $\begin{array}{l}\text { PS weighted } \\
\text { (2) }\end{array}$ & $\begin{array}{l}\text { PS weighted } \\
\text { (3) }\end{array}$ & $\begin{array}{l}\text { PS weighted } \\
\text { (4) }\end{array}$ & $\begin{array}{l}\text { PS weighted } \\
\text { (5) }\end{array}$ & $\begin{array}{l}\text { PS weighted } \\
\text { (6) }\end{array}$ \\
\hline \multicolumn{8}{|l|}{ Outcome } \\
\hline \multirow[t]{4}{*}{ Total exports } & Treatment*Export Cell & 0.217 & 0.336 & 0.071 & -0.090 & -0.352 & -0.184 \\
\hline & & {$[0.173]$} & [0.211] & {$[0.243]$} & {$[0.333]$} & [0.433] & [0.403] \\
\hline & Treatment*No Export Cell & $0.604 * *$ & $0.641 * *$ & 0.349 & 0.239 & 0.389 & 0.508 \\
\hline & & {$[0.267]$} & {$[0.300]$} & {$[0.309]$} & {$[0.355]$} & {$[0.433]$} & {$[0.472]$} \\
\hline \multicolumn{2}{|l|}{$R$-squared } & 0.794 & 0.770 & 0.765 & 0.762 & 0.746 & 0.741 \\
\hline \multirow[t]{4}{*}{$\mathrm{Nb}$. destinations } & Treatment*Export Cell & $0.079 * * *$ & $0.092 * * *$ & $0.073 *$ & -0.009 & -0.049 & 0.008 \\
\hline & & {$[0.028]$} & {$[0.033]$} & {$[0.040]$} & {$[0.045]$} & {$[0.062]$} & {$[0.062]$} \\
\hline & Treatment*No Export Cell & $0.130 * * *$ & $0.131 * * *$ & $0.079 *$ & 0.052 & 0.022 & 0.072 \\
\hline & & {$[0.033]$} & [0.037] & {$[0.042]$} & {$[0.042]$} & {$[0.056]$} & [0.059] \\
\hline \multicolumn{2}{|l|}{$R$-squared } & 0.840 & 0.825 & 0.813 & 0.807 & 0.787 & 0.783 \\
\hline \multirow[t]{4}{*}{$\mathrm{Nb}$. products } & Treatment*Export Cell & 0.015 & 0.036 & 0.001 & $-0.116^{*}$ & -0.044 & 0.055 \\
\hline & & {$[0.039]$} & [0.047] & {$[0.053]$} & {$[0.063]$} & {$[0.072]$} & {$[0.073]$} \\
\hline & Treatment*No Export Cell & $0.157 * * *$ & $0.128 * * *$ & $0.125^{* *}$ & 0.060 & 0.029 & 0.091 \\
\hline & & {$[0.045]$} & [0.049] & {$[0.052]$} & {$[0.058]$} & {$[0.068]$} & {$[0.077]$} \\
\hline \multicolumn{2}{|l|}{$R$-squared } & 0.800 & 0.783 & 0.774 & 0.762 & 0.755 & 0.755 \\
\hline \multicolumn{2}{|l|}{ Observations } & 18,805 & 21,089 & 21,077 & 18,638 & 13,802 & 9,197 \\
\hline \multicolumn{8}{|c|}{ Fixed effects included in 3 regressions above } \\
\hline \multicolumn{2}{|l|}{ Firm } & Yes & Yes & Yes & Yes & Yes & Yes \\
\hline \multicolumn{2}{|l|}{ Sector-year } & Yes & Yes & Yes & Yes & Yes & Yes \\
\hline
\end{tabular}

Notes: robust standard errors in brackets; *: significant at 10\%; **: significant at 5\%; ***: significant at $1 \%$. Each cell with 2 coefficients, 2 standard errors, and an R-squared in the table corresponds to a separate regression (18 regressions in all). The other firm covariates whose coefficients are omitted for brevity are: the lagged share of exports to high-income destinations, the lagged share of exports to MENA countries, the lagged average distance to export destinations, the lagged export shares by HS section, and the lagged average unit value by HS 6-digit relative to the sample average. The non-interacted export cell dummy is absorbed by the firm fixed effects.

\section{Explaining the temporariness of FAMEX effects}

In this section, we begin by examining the role of spillovers, which could lead to catching-up by non-beneficiary firms. Second, we look at whether treated firms had become more exposed than control ones to crisis-affected economies. Next, we explore more structural explanations relating to the limitations of FAMEX's short-lived, arm's-length intervention. In particular, we decompose treatment effects by treatment "arm" (what type of assistance it delivered), and examine whether treatment effects were felt on other dimensions of firm performance, like product sophistication or quality.

\subsection{Spillovers and catch-up by control firms}

One reason for the lack of persistence of treatment effects could be catching up by control firms, rather than vanishing benefits for treated firms. For instance, FAMEX beneficiaries' actions, such as participating in trade fairs or hiring export-marketing consultants, could have been visible to 
and easily imitated by other firms in their sector or location. Information acquired by FAMEX beneficiaries might even have been shared voluntarily with other firms, as exporters from the same country do not necessarily see themselves as competitors on foreign markets. ${ }^{26}$ This is not just a technical issue. Non-appropriability of benefits from information production (e.g., marketing research) in the presence of externalities can be seen as the market failure justifying the subsidized intervention by the Tunisian government and the World Bank. ${ }^{27}$

The difficulty in investigating this issue explicitly is that the measurement of spillovers is elusive, especially when the transmission channel is unknown. Following standard practice in the literature, our spillover proxy is defined as a time-variant count of the number of FAMEX beneficiaries in each sector-region-year cell in a given year $t-k, n_{i s(i) r(i), t-k}$, where $s(i)$ and $r(i)$ are respectively firm $i$ 's sector and region. This assumes that firms are more likely to benefit from externalities if they produce similar goods in the same location. ${ }^{28} \mathrm{We}$ then regress control firm export outcomes on exposure to FAMEX beneficiaries. ${ }^{29}$ That is,

$$
\ln \left(y_{i t}\right)=\sum_{\ell} \beta_{\ell} n_{s(i) r(i), t-\ell}+\delta_{i}+\delta_{s t}+\delta_{r t}+v_{i t} \quad \text { for } i \in C
$$

where $\delta_{i}$ are firm fixed effects, $\delta_{s t}$ are sector-year fixed effects and $\delta_{r t}$ are location-year fixed effects that control for unobserved shocks affecting both outcomes and the number of firms receiving FAMEX support in a sector or region. The exposure variable enters with various lags to mitigate endogeneity and, more importantly, to allow for the slow diffusion of externalities.

Estimates for Eq. (7) shown in Table 11 do not reveal evidence of any positive externalities; indeed, the only instances of significant coefficients for total exports in column (1) and for the number of products in column (12) are negative. We re-estimated a variant of Eq. (7) with a sample

\footnotetext{
${ }^{26}$ Cadot, Iacovone, Pierola, and Rauch (2013) show that, for African exporters, expected survival rises with the number of firms from the same country exporting the same product to the same destination. Whether export entrepreneurship creates externalities that need to be supported by public action, as argued e.g. in Hausmann and Rodrik (2003), is still largely an open question.

${ }^{27}$ The fact that potential exporters are not fully informed about foreign market opportunities is not sufficient, in itself, to create a market failure if information production is costly but appropriable. By contrast, a market failure could arise in the presence of imperfect appropriability of the information. Indeed, Volpe and Carballo (2008), citing McDermott (1994), note that "customer lists are the most common target of corporate spies." Credit rationing is another market failure that could justify intervention. However, if the government provided export credit services in lieu of deficient financial markets, the benefits would be appropriable and the services should be extended on a full-cost recovery basis rather than as a matching grant.

${ }^{28}$ Empirical studies such as Aitken, Hanson, and Harrison (1997), Bernard and Jensen (2004) and Kneller and Pisu (2007) use the presence of exporters in an industry and location to capture export spillovers while Koenig, Mayneris, and Poncet (2010) and Mayneris and Poncet (2010) use the numbers of exporters in the same region exporting similar products and/or to similar destinations. Krautheim (2012) develops a trade model with heterogeneous firms including a spillover effect from the number of exporters to the fixed costs of exporting.

${ }^{29}$ One weakness with this approach is that we are unable to measure spillovers on Tunisian firms other than the control firms in our sample because we were not allowed access to data on the universe of Tunisian firms. Another weakness is that we cannot explore spillovers on outcomes other than exports, again due to data limitations.
} 
including all firms, both FAMEX beneficiaries and control firms, and again found no evidence of externalities. We also considered the possibility that spillovers to control firms were more likely to emerge from FAMEX firms whose objective was to expand into new destinations or to export new products (visible and easily imitable moves), by re-estimating Eq. (7) using a variant of the exposure variable counting only those. The evidence that this smaller set of FAMEX firms generated external benefits for proximate control firms is also weak. ${ }^{30}$ Although our results must be interpreted cautiously, our explanatory variable being only an imperfect proxy for unobserved spillovers, they do not suggest that catching up through spillovers was a cause of the rapidly vanishing FAMEX treatment effects.

Table 11: Effects of exposure to FAMEX firms on control firms' export outcomes

\begin{tabular}{|c|c|c|c|c|c|c|c|c|c|c|c|c|}
\hline \multirow{5}{*}{$\begin{array}{l}\text { Forwarding degree } \\
\text { Estimator } \\
\text { Outcome }\end{array}$} & \multicolumn{4}{|c|}{$\mathrm{t}(k=0)$} & \multicolumn{4}{|c|}{$\mathrm{t}(k=0)$} & \multicolumn{4}{|c|}{$\mathrm{t}(k=0)$} \\
\hline & \multicolumn{4}{|c|}{ OLS } & \multicolumn{4}{|c|}{ OLS } & \multicolumn{4}{|c|}{ OLS } \\
\hline & \multicolumn{4}{|c|}{ Total exports } & \multicolumn{4}{|c|}{ Nb. destinations } & \multicolumn{4}{|c|}{ Nb. products } \\
\hline & \multicolumn{4}{|c|}{ Sample of control firms only } & \multicolumn{4}{|c|}{ Sample of control firms only } & \multicolumn{4}{|c|}{ Sample of control firms only } \\
\hline & (1) & (2) & (3) & (4) & $(5)$ & $(6)$ & (7) & $(8)$ & (9) & $(10)$ & $(11)$ & $(12)$ \\
\hline \multirow[t]{2}{*}{ Exposure to FAMEX benef. $\mathrm{t}-1$} & -0.032 & -0.027 & -0.033 & $-0.069 * *$ & -0.003 & -0.004 & -0.003 & $-0.005^{*}$ & -0.005 & -0.006 & -0.005 & $-0.008 *$ \\
\hline & {$[0.025]$} & [0.026] & [0.028] & {$[0.032]$} & [0.003] & [0.003] & {$[0.003]$} & {$[0.003]$} & [0.003] & [0.004] & [0.004] & {$[0.004]$} \\
\hline \multirow[t]{2}{*}{ Exposure to FAMEX benef. $\mathrm{t}-2$} & & 0.024 & 0.018 & -0.016 & & -0.002 & -0.002 & -0.004 & & -0.001 & 0.000 & -0.003 \\
\hline & & [0.027] & [0.029] & [0.032] & & [0.003] & [0.003] & {$[0.003]$} & & [0.004] & [0.004] & {$[0.004]$} \\
\hline \multirow[t]{2}{*}{ Exposure to FAMEX benef. $\mathrm{t}-3$} & & & -0.003 & -0.035 & & & 0.000 & -0.002 & & & 0.003 & -0.001 \\
\hline & & & [0.028] & [0.031] & & & [0.003] & [0.003] & & & [0.004] & [0.004] \\
\hline \multirow[t]{2}{*}{ Exposure to FAMEX benef. t- 4} & & & & $-0.067 * *$ & & & & $-0.007 * *$ & & & & $-0.011 * * *$ \\
\hline & & & & [0.029] & & & & [0.003] & & & & {$[0.004]$} \\
\hline$R$-squared & 0.071 & 0.082 & 0.094 & 0.119 & 0.064 & 0.073 & 0.084 & 0.111 & 0.069 & 0.080 & 0.091 & 0.114 \\
\hline Observations & 19,319 & 17,272 & 15,092 & 12,785 & 19,319 & 17,272 & 15,092 & 12,785 & 19,319 & 17,272 & 15,092 & 12,785 \\
\hline \multicolumn{13}{|c|}{ Fixed effects included in regression above } \\
\hline Firm & Yes & Yes & Yes & Yes & Yes & Yes & Yes & Yes & Yes & Yes & Yes & Yes \\
\hline Sector-year & Yes & Yes & Yes & Yes & Yes & Yes & Yes & Yes & Yes & Yes & Yes & Yes \\
\hline Location-year & Yes & Yes & Yes & Yes & Yes & Yes & Yes & Yes & Yes & Yes & Yes & Yes \\
\hline
\end{tabular}

Notes: robust standard errors in brackets; $*$ significant at 10\%; ** significant at $5 \%$.

\subsection{Exposure to the Global Financial Crisis}

The temporariness of FAMEX effects could also be due to the impact of the Global Financial Crisis (GFC), which coincided with the last part of our sample period and strongly affected E.U. countries which were important destinations for Tunisian exporters. However, this is unlikely to be an explanation for the temporariness of treatment effects for a number of reasons. First, our effects on total exports and on the number of exported products disappear two years after treatment, which, for the majority of treated firms (those treated in 2005) corresponds to outcomes in 2007, a year before the onset of the GFC. Indeed, estimating Eq. (6) based only on the 2005 FAMEX cohort (along with all control firms) yields the same pattern of non-persistent effects on total exports after two years in Panel A of Table 12. Second, our results are obtained from PS weighted regressions with firm fixed effects which, like difference-in-differences regressions, purge

\footnotetext{
${ }^{30}$ The results from these two additional spillover regressions are available in the online appendix.
} 
macroeconomic shocks such as the GFC affecting all firms. Third, our specifications control for sector-year fixed effects addressing specifically the possibility of macroeconomic shocks that have differential sectoral effects. Fourth, there is no evidence that FAMEX recipient firms expanded more in E.U. markets, exposing them more than control firms to the GFC. Taking the firm share of exports to E.U. markets as an outcome, treatment effects are not significant in Panel B of Table 12, suggesting that FAMEX did not significantly alter Tunisian firms' export portfolios toward E.U. destinations.

Table 12: FAMEX treatment effects and the Global Financial Crisis estimated by PS weighted

\begin{tabular}{|c|c|c|c|c|c|c|}
\hline \multicolumn{7}{|c|}{ regression } \\
\hline Forwarding degree & $\mathrm{TY}(k=0)$ & $\mathrm{TY}+1(k=1)$ & $\mathrm{TY}+2(k=2)$ & $\mathrm{TY}+3(k=3)$ & $\mathrm{TY}+4(k=4)$ & $\mathrm{TY}+5(k=5)$ \\
\hline Estimator & $\begin{array}{l}\text { PS weighted } \\
\text { (1) }\end{array}$ & $\begin{array}{l}\text { PS weighted } \\
\text { (2) }\end{array}$ & $\begin{array}{l}\text { PS weighted } \\
\text { (3) }\end{array}$ & $\begin{array}{l}\text { PS weighted } \\
\text { (4) }\end{array}$ & $\begin{array}{l}\text { PS weighted } \\
\text { (5) }\end{array}$ & $\begin{array}{l}\text { PS weighted } \\
\text { (6) }\end{array}$ \\
\hline \multicolumn{7}{|c|}{$\begin{array}{l}\text { Panel A: Sample includes } 2005 \text { FAMEX cohort only and control firms } \\
\text { Outcome }\end{array}$} \\
\hline Total exports & $\begin{array}{l}0.611 * * * \\
{[0.204]}\end{array}$ & $\begin{array}{l}0.743 * * * \\
{[0.238]}\end{array}$ & $\begin{array}{l}0.278 \\
{[0.242]}\end{array}$ & $\begin{array}{l}0.057 \\
{[0.271]}\end{array}$ & $\begin{array}{l}-0.016 \\
{[0.325]}\end{array}$ & $\begin{array}{l}0.144 \\
{[0.327]}\end{array}$ \\
\hline$R$-squared & 0.781 & 0.758 & 0.758 & 0.754 & 0.742 & 0.740 \\
\hline $\mathrm{Nb}$. destinations & $\begin{array}{l}0.140^{* * * *} \\
{[0.028]}\end{array}$ & $\begin{array}{l}0.136 * * * \\
{[0.031]}\end{array}$ & $\begin{array}{l}0.109 * * * \\
{[0.034]}\end{array}$ & $\begin{array}{l}0.051 \\
{[0.039]}\end{array}$ & $\begin{array}{l}0.024 \\
{[0.045]}\end{array}$ & $\begin{array}{l}0.039 \\
{[0.045]}\end{array}$ \\
\hline$R$-squared & 0.836 & 0.821 & 0.814 & 0.800 & 0.783 & 0.783 \\
\hline $\mathrm{Nb}$. products & $\begin{array}{l}0.126^{* * *} \\
{[0.039]}\end{array}$ & $\begin{array}{l}0.079^{*} \\
{[0.042]}\end{array}$ & $\begin{array}{l}0.060 \\
{[0.043]}\end{array}$ & $\begin{array}{l}0.030 \\
{[0.051]}\end{array}$ & $\begin{array}{l}0.032 \\
{[0.057]}\end{array}$ & $\begin{array}{l}0.072 \\
{[0.055]}\end{array}$ \\
\hline$R$-squared & 0.795 & 0.784 & 0.781 & 0.762 & 0.755 & 0.755 \\
\hline \multicolumn{6}{|c|}{ Fixed effects included in 3 regressions above } & 9,197 \\
\hline Firm & Yes & Yes & Yes & Yes & Yes & Yes \\
\hline Sector-year & Yes & Yes & Yes & Yes & Yes & Yes \\
\hline \multicolumn{7}{|c|}{$\begin{array}{l}\text { Panel B. Sample includes all FAMEX cohorts and control firms } \\
\text { Outcome }\end{array}$} \\
\hline Share of exports to EU dest. & $\begin{array}{l}0.019 \\
{[0.013]}\end{array}$ & $\begin{array}{l}-0.005 \\
{[0.015]}\end{array}$ & $\begin{array}{l}0.003 \\
{[0.016]}\end{array}$ & $\begin{array}{c}-0.031 * \\
{[0.019]}\end{array}$ & $\begin{array}{l}-0.037 \\
{[0.023]}\end{array}$ & $\begin{array}{l}-0.027 \\
{[0.022]}\end{array}$ \\
\hline$R$-squared & 0.814 & 0.799 & 0.780 & 0.782 & 0.778 & 0.780 \\
\hline Observations & 18,805 & 21,089 & 21,077 & 18,638 & 13,802 & 9,197 \\
\hline \multicolumn{7}{|c|}{ Fixed effects included in regression above } \\
\hline Firm & Yes & Yes & Yes & Yes & Yes & Yes \\
\hline Sector-year & Yes & Yes & Yes & Yes & Yes & Yes \\
\hline
\end{tabular}

Notes: robust standard errors in brackets; ${ }^{*}$ significant at 10\%; ** significant at 5\%. Each cell with a coefficient, a standard error, and an R-squared in each of the panels of the table corresponds to a separate regression (18 regressions in all). The other firm covariates whose coefficients are omitted for brevity are: the lagged share of exports to high-income destinations, the lagged share of exports to MENA countries, the lagged average distance to export destinations, the lagged export shares by HS section, and the lagged average unit value by HS 6-digit relative to the sample average.

\subsection{Design and attributes of the FAMEX program}

We now turn to more structural explanations for the temporariness of treatment effects, using our dataset's information on FAMEX components. Our detailed program data allows us to decompose the treatment effect into its different "arms" or activities - market prospection (going to trade fairs), promotion (putting up stands in trade fairs), and other dimensions like product or process 
development. Table 1 showed that most of FAMEX's resources went to market prospection and promotion activities. Table 13 shows results from estimating Eq. (6) with activity dummies (instead of the treatment dummy). Only market prospection has significant treatment effects on total exports and the number of destinations, but even those effects are transient. Potentially important firm- and product-development activities present a dismal picture of insignificant and sometimes even negative impact, suggesting that "deeper" assistance activities provided by FAMEX were largely ineffectual. It may not have been feasible to accomplish meaningful changes in product and firm development with an intervention that lasted a year or less.

Table 13: FAMEX treatment effects by type of intervention estimated by PS weighted

\begin{tabular}{|c|c|c|c|c|c|c|c|}
\hline \multicolumn{8}{|c|}{$x_{1}^{2}$} \\
\hline \multirow{2}{*}{\multicolumn{2}{|c|}{$\begin{array}{l}\text { Forwarding degree } \\
\text { Estimator }\end{array}$}} & $\mathrm{TY}(k=0)$ & $\mathrm{TY}+1(k=1)$ & $\mathrm{TY}+2(k=2)$ & $\mathrm{TY}+3(k=3)$ & $\mathrm{TY}+4(k=4)$ & $\mathrm{TY}+5(k=5)$ \\
\hline & & $\begin{array}{l}\text { PS weighted } \\
\text { (1) }\end{array}$ & $\begin{array}{l}\text { PS weighted } \\
\text { (2) }\end{array}$ & $\begin{array}{l}\text { PS weighted } \\
\text { (3) }\end{array}$ & $\begin{array}{l}\text { PS weighted } \\
\text { (4) }\end{array}$ & $\begin{array}{l}\text { PS weighted } \\
\text { (5) }\end{array}$ & $\begin{array}{l}\text { PS weighted } \\
\text { (6) }\end{array}$ \\
\hline \multirow[t]{5}{*}{ Outcome } & Activity dummies & & & & & & \\
\hline & Market prospection & 0.560 & $1.201 * *$ & $1.035^{*}$ & 0.886 & 0.662 & 1.250 \\
\hline & & {$[0.403]$} & [0.507] & [0.554] & {$[0.552]$} & {$[0.767]$} & [0.827] \\
\hline & Promotion & 0.239 & -0.279 & -0.477 & -0.303 & 0.495 & -0.447 \\
\hline & & {$[0.406]$} & [0.481] & {$[0.520]$} & {$[0.537]$} & {$[0.731]$} & {$[0.765]$} \\
\hline \multirow{7}{*}{ Total exports } & Product development & 0.008 & -0.313 & 0.130 & -0.152 & $-1.459 * * *$ & -0.368 \\
\hline & & {$[0.354]$} & {$[0.391]$} & {$[0.403]$} & [0.434] & {$[0.563]$} & [0.659] \\
\hline & Firm development & $-0.726^{* *}$ & $-0.706^{*}$ & -0.536 & -0.467 & -0.350 & -0.866 \\
\hline & & {$[0.345]$} & [0.381] & [0.405] & {$[0.431]$} & {$[0.558]$} & {$[0.636]$} \\
\hline & Foreign subs. creation & 0.020 & 0.590 & -0.171 & 0.229 & -0.501 & -0.474 \\
\hline & & {$[0.496]$} & [0.477] & [0.534] & {$[0.516]$} & {$[0.781]$} & {$[0.943]$} \\
\hline & $R$-squared & 0.788 & 0.771 & 0.765 & 0.763 & 0.748 & 0.741 \\
\hline \multirow[t]{5}{*}{ Outcome } & Activity dummies & & & & & & \\
\hline & Market prospection & $0.102^{* *}$ & $0.172 * * *$ & 0.078 & 0.089 & 0.077 & 0.142 \\
\hline & & {$[0.049]$} & {$[0.060]$} & [0.072] & {$[0.078]$} & {$[0.110]$} & {$[0.124]$} \\
\hline & Promotion & 0.053 & -0.050 & 0.051 & -0.018 & 0.083 & 0.035 \\
\hline & & {$[0.048]$} & {$[0.059]$} & {$[0.070]$} & {$[0.075]$} & {$[0.103]$} & {$[0.112]$} \\
\hline \multirow{7}{*}{ Nb. destinations } & Product development & $0.102^{* *}$ & 0.024 & $0.113^{*}$ & 0.010 & $-0.174 * *$ & -0.024 \\
\hline & & {$[0.050]$} & {$[0.055]$} & {$[0.061]$} & {$[0.065]$} & {$[0.087]$} & {$[0.097]$} \\
\hline & Firm development & $-0.123 * * *$ & -0.035 & -0.049 & -0.015 & -0.052 & $-0.149 *$ \\
\hline & & {$[0.047]$} & {$[0.050]$} & {$[0.057]$} & {$[0.059]$} & {$[0.082]$} & {$[0.090]$} \\
\hline & Foreign subs. creation & -0.014 & 0.057 & -0.005 & -0.068 & -0.098 & -0.187 \\
\hline & & {$[0.063]$} & {$[0.067]$} & {$[0.080]$} & {$[0.080]$} & {$[0.104]$} & {$[0.123]$} \\
\hline & $R$-squared & 0.839 & 0.825 & 0.815 & 0.807 & 0.789 & 0.785 \\
\hline \multirow[t]{5}{*}{ Outcome } & Activity dummies & & & & & & \\
\hline & Market prospection & 0.030 & 0.020 & 0.035 & -0.058 & -0.085 & 0.068 \\
\hline & & {$[0.079]$} & [0.099] & {$[0.105]$} & [0.111] & {$[0.129]$} & {$[0.145]$} \\
\hline & Promotion & 0.076 & 0.007 & 0.023 & 0.048 & 0.100 & -0.056 \\
\hline & & {$[0.075]$} & [0.087] & [0.094] & {$[0.096]$} & {$[0.117]$} & {$[0.122]$} \\
\hline \multirow{8}{*}{$\mathrm{Nb}$. products } & Product development & -0.018 & 0.037 & 0.049 & 0.092 & -0.118 & 0.153 \\
\hline & & {$[0.072]$} & [0.077] & {$[0.076]$} & {$[0.085]$} & {$[0.109]$} & [0.119] \\
\hline & Firm development & -0.062 & 0.014 & -0.001 & 0.067 & $0.188^{*}$ & 0.103 \\
\hline & & {$[0.065]$} & {$[0.070]$} & {$[0.073]$} & {$[0.082]$} & {$[0.101]$} & {$[0.110]$} \\
\hline & Foreign subs. creation & $0.151^{*}$ & $0.167 * *$ & -0.044 & -0.002 & -0.065 & -0.048 \\
\hline & & {$[0.087]$} & {$[0.083]$} & {$[0.084]$} & {$[0.107]$} & {$[0.144]$} & {$[0.176]$} \\
\hline & $R$-squared & 0.801 & 0.783 & 0.774 & 0.761 & 0.756 & 0.756 \\
\hline & Observations & 18,732 & 21,089 & 21,077 & 18,638 & 13,802 & 9,197 \\
\hline \multicolumn{8}{|c|}{ Fixed effects included in 3 regressions above } \\
\hline \multirow{2}{*}{\multicolumn{2}{|c|}{$\begin{array}{l}\text { Firm } \\
\text { Sector-year }\end{array}$}} & Yes & Yes & Yes & Yes & Yes & Yes \\
\hline & & Yes & Yes & Yes & Yes & Yes & Yes \\
\hline
\end{tabular}

Notes: robust standard errors in brackets; $*$ significant at 10\%; ** significant at 5\%. Each cell with a coefficient, a standard error, and an R-squared in the table corresponds to a separate regression (18 regressions in all). The other firm covariates whose coefficients are omitted for brevity are: the lagged share of exports to high-income destinations, the lagged share of exports to 
MENA countries, the lagged average distance to export destinations, the lagged export shares by HS section, and the lagged average unit value by HS 6-digit relative to the sample average.

The results above on treatment arms show that FAMEX assistance to product or process improvement had no effect on export outcomes. This may have been because FAMEX put too little emphasis on product quality improvements that could have durably enhanced firm competitiveness. Improving quality and reliability to match industrial country standards is a traditional hurdle for developing country exporters that might call for deeper interventions than just export promotion. The recent randomized control trial that generates exogenous variation in the opportunity to export for Egyptian rug producing firms shows that product quality is important for export success (Atkin, Khandelwal, and Osman, 2015). In order to get direct evidence on how export quality evolved after FAMEX, we tested whether treatment effects were identifiable on relative unit values as defined in Eq. (4). Although our five-year horizon was in theory sufficiently long to allow time for quality improvements, in practice treatment effects were not significant. FAMEX also did not have a significant effect on an export-weighted average of product sophistication for Tunisian firms, as proxied by the PRODY index (Hausmann, Hwang, and Rodrik 2007). ${ }^{31}$ In the same vein, based on Eq. (3), we explored whether FAMEX induced beneficiaries to increase the average distance to their export destinations (since export participation in markets with higher fixed and variable costs correlates positively with firm productivity, a rising average distance to export destinations could be interpreted as an indicator of better in-firm processes leading to higher productivity following Eaton, Kortum, and Kramarz (2011)). We also explored whether FAMEX led firms to orient their export portfolio more towards high-income destinations, generally considered to be more demanding in terms of product quality. Results are shown in Table 14. Average distance to export destinations rises but only in the first two years for FAMEX firms relative to control firms. The share of exports to high-income destinations increases in the year of treatment but the significance of the effect is only at the 10 percent confidence level and the effect disappears in subsequent years. All in all, the pattern is not one of no effect at all, but again of weak and transient effects.

\footnotetext{
${ }^{31}$ A product's PRODY index is a weighted average of the income level (GDP) of countries exporting it, with weights $w_{\text {okt }}$ given by a modified version of the Balassa index of exporting country $o$ in product $k$. The intuition is that more sophisticated products tend to be exported by high-income countries. We calculate a firm-level average PRODY $q_{i t}$ comparable to Hausman et al.'s country-level EXPY as a weighted average, using as weights the firm-product-year export shares $w_{i k t}$. That is, $P R O D Y_{k t}=\sum_{o} w_{o k t} G D P_{o t}$ and $q_{i t}=\sum_{k} w_{i k t}$ PRODY $_{k}$.
} 
Table 14: FAMEX treatment effects on other performance variables estimated by PS weighted regression

\begin{tabular}{|c|c|c|c|c|c|c|}
\hline $\begin{array}{l}\text { Forwarding degree } \\
\text { Estimator }\end{array}$ & $\begin{array}{l}\text { TY }(k=0) \\
\text { PS weighted } \\
(1)\end{array}$ & $\begin{array}{l}\text { TY+1 }(k=1) \\
\text { PS weighted } \\
(2)\end{array}$ & $\begin{array}{l}\mathrm{TY}+2(k=2) \\
\text { PS weighted } \\
\text { (3) }\end{array}$ & $\begin{array}{l}\text { TY+3 }(k=3) \\
\text { PS weighted } \\
\text { (4) }\end{array}$ & $\begin{array}{l}\text { TY+4 }(k=4) \\
\text { PS weighted } \\
(5)\end{array}$ & $\begin{array}{l}\mathrm{TY}+5(k=5) \\
\text { PS weighted } \\
(6)\end{array}$ \\
\hline \multicolumn{7}{|l|}{ Outcome } \\
\hline Average unit value by HS 6-digit & $\begin{array}{l}0.034 \\
{[0.030]}\end{array}$ & $\begin{array}{l}0.040 \\
{[0.038]}\end{array}$ & $\begin{array}{l}-0.022 \\
{[0.036]}\end{array}$ & $\begin{array}{l}0.010 \\
{[0.039]}\end{array}$ & $\begin{array}{l}-0.057 \\
{[0.049]}\end{array}$ & $\begin{array}{l}0.017 \\
{[0.043]}\end{array}$ \\
\hline$R$-squared & 0.648 & 0.610 & 0.633 & 0.650 & 0.625 & 0.617 \\
\hline Observations & 18,805 & 21,089 & 21,077 & 18,638 & 13,802 & 9,197 \\
\hline Product sophistication index & $\begin{array}{l}0.241 \\
{[0.152]}\end{array}$ & $\begin{array}{l}0.362 * * \\
{[0.178]}\end{array}$ & $\begin{array}{l}0.150 \\
{[0.171]}\end{array}$ & $\begin{array}{l}0.044 \\
{[0.232]}\end{array}$ & $\begin{array}{l}0.032 \\
{[0.293]}\end{array}$ & $\begin{array}{l}0.071 \\
{[0.257]}\end{array}$ \\
\hline$R$-squared & 0.690 & 0.665 & 0.664 & 0.658 & 0.646 & 0.647 \\
\hline Observations & 18,805 & 21,089 & 21,077 & 18,638 & 13,802 & 9,197 \\
\hline Average distance to export destinations & $\begin{array}{l}0.215^{* *} \\
{[0.107]}\end{array}$ & $\begin{array}{l}0.264 * * \\
{[0.124]}\end{array}$ & $\begin{array}{l}0.132 \\
{[0.124]}\end{array}$ & $\begin{array}{l}0.007 \\
{[0.168]}\end{array}$ & $\begin{array}{l}0.133 \\
{[0.206]}\end{array}$ & $\begin{array}{l}0.091 \\
{[0.182]}\end{array}$ \\
\hline$R$-squared & 0.691 & 0.661 & 0.660 & 0.665 & 0.651 & 0.654 \\
\hline Observations & 18,645 & 20,921 & 20,910 & 18,485 & 13,686 & 9,121 \\
\hline Share of exports to high-income destinations & $\begin{array}{l}0.025^{*} \\
{[0.013]}\end{array}$ & $\begin{array}{l}-0.007 \\
{[0.015]}\end{array}$ & $\begin{array}{l}0.014 \\
{[0.016]}\end{array}$ & $\begin{array}{l}-0.012 \\
{[0.021]}\end{array}$ & $\begin{array}{l}-0.027 \\
{[0.023]}\end{array}$ & $\begin{array}{l}-0.023 \\
{[0.022]}\end{array}$ \\
\hline$R$-squared & 0.807 & 0.795 & 0.778 & 0.768 & 0.769 & 0.767 \\
\hline Observations & 18,805 & 21,089 & 21,077 & 18,638 & 13,802 & 9,197 \\
\hline Fixed effects included in all regressions above & & & & & & \\
\hline Firm & Yes & Yes & Yes & Yes & Yes & Yes \\
\hline Sector-year & Yes & Yes & Yes & Yes & Yes & Yes \\
\hline
\end{tabular}

Notes: robust standard errors in brackets; *: significant at $10 \%$; **: significant at 5\%; ***: significant at $1 \%$. Each cell with a coefficient, a standard error, and an R-squared in the table corresponds to a separate regression (18 regressions in all). The other firm covariates whose coefficients are omitted for brevity are: the lagged share of exports to high-income destinations, the lagged share of exports to MENA countries, the lagged average distance to export destinations, the lagged export shares by HS section, and the lagged average unit value by HS 6-digit relative to the sample average. The product sophistication index is defined in footnote 31 .

\subsection{A Tentative cost-benefit analysis}

Our results suggest that FAMEX had a positive —albeit transient—effect on total exports of treated firms. We turn in this section to a tentative cost-benefit calculation to estimate the rate of return of the FAMEX program, laying out clearly the assumptions made at each step. In Table 15 we assume that the FAMEX program generates additional exports for treated firms only in the years when the treatment effects in Table 8 are significant, i.e., in TY and TY+1. To calculate the additional exports generated by FAMEX, we obtain for each FAMEX firm the counterfactual exports had it not benefitted from the program based on $\log$ total exports $y_{i t}$ and Table 8's coefficients as $y_{i t}$ 0.411 if $t=\mathrm{TY}$ and $y_{i t}-0.486$ if $t=\mathrm{TY}+1$, and we exponentiate these values to get exports in levels. Then we obtain the sum of total exports of all FAMEX firms in years TY and TY+1 (row (a)) and the sum of counterfactual exports of all FAMEX firms in years TY and TY+1 (row (b)). The difference between rows (a) and (b) gives the additional exports generated by the FAMEX 
program, shown in row (c). We discount these additional exports at an annual discount rate of 8 percent in row $(\mathrm{d}) .^{32}$

Drawing on information on median profit margins for Tunisian manufacturing firms over the 20052010 period obtained from Tunisia's National Statistical Institute, we assume that the profit margin over the additional export revenues generated by FAMEX is 5 percent and we show the resulting total profits from the additional export revenues in row (e). Applying the Tunisian corporate income tax rate of 30 percent to those profits, we calculate the benefit of the FAMEX program to the Tunisian government as 14.45 million Tunisian Dinars in tax revenue from the additional exports generated by FAMEX (total in row (f)).

Combining the total value of the grants provided by the FAMEX program to firms in our estimating sample (which we measure accurately in our dataset) with approximate overhead administrative and operational costs of the FAMEX program taken from World Bank project documents, we calculate the total cost of the FAMEX program to be 14.2 million Tunisian Dinars (row $(\mathrm{g})$ ). ${ }^{33}$ The ratio of the tax revenue to the cost of the program (to the Tunisian Government and the World Bank) gives a public benefit-cost ratio of 1.02 (row (h)).

We also calculate the benefit-cost ratio for the private sector from the FAMEX program. The measure of the benefits from the program for firms are the net after-tax additional total profits of 33.72 million Tunisian Dinars (total in row (i)) while the cost for firms is the matching of the grants provided by the FAMEX program that firms need to pay. We assume for the calculations that all firms put up an amount equal to the grant amount and the total matching grants are thus 9.44 million Tunisian Dinars (row (j)) ${ }^{34}$ The ratio of net after-tax total profits to the costs of the program for firms gives a private benefit-cost ratio of 3.57 (row $(\mathrm{k})$ ).

The fact that the sum of additional private net after-tax profits and tax revenues (48.17 million Tunisian Dinars in row (e)) is greater than the total private and public cost of the FAMEX program (23.64 million Tunisian Dinars in row (1)) suggests that it was socially desirable. The fact that the additional tax revenue is slightly higher than the costs of the FAMEX program suggests that it was, in principle, possible to run it on a cost-recovery basis without external assistance. The fact

\footnotetext{
${ }^{32}$ This discount rate was chosen because it was used for the cost-benefit analyses in the World Bank FAMEX project documents.

${ }^{33}$ The total management and operational costs of the FAMEX program listed in those documents are 12.87 million Tunisian Dinars ( 9 million USD). We reduce this value by 60 percent, given that our estimating sample includes only about 40 percent of the full set of firms that received the FAMEX program (in particular, as indicated in Section 2, our sample excludes services firms and firms whose FAMEX plan was ongoing at the end of 2009). Thus we consider management and operational costs of the FAMEX program of 4.76 million Tunisian Dinars while the total value of the grants provided by the FAMEX program to firms in our estimating sample was 9.44 million Tunisian Dinars.

${ }^{34}$ This is an upper bound to the total amount put up as a matching grant by the firms given that, as mentioned in Section 2 , the FAMEX program provided up to 50 percent - not 50 percent always - of the costs of the export business plan proposed by the firm.
} 
that FAMEX firms' net after-tax private profits (row (i)) are larger than not just firms' own costs (row (j)) but also total costs of the program (row (1)) suggests a high degree of internalization of the benefits and raises the question of whether the firms needed the program in order to undertake the export promotion activities. Of course, credit market imperfections, which prevent firms from borrowing against future benefits, and information asymmetries, which mean that firms are not fully aware of the benefits of investing in export promotion activities, could still provide a rationale for the FAMEX program.

Table 15: Tentative benefit-cost ratios

\begin{tabular}{|c|c|c|c|c|c|c|c|c|}
\hline & TY & $\mathrm{TY}+1$ & $\mathrm{TY}+2$ & $\mathrm{TY}+3$ & $\mathrm{TY}+4$ & $\mathrm{TY}+5$ & Total & Ratio \\
\hline (a) Total exports of all FAMEX firms (in millions of TD) & 1352.26 & 1433.42 & \multirow{3}{*}{\multicolumn{4}{|c|}{$\begin{array}{l}\text { Difference across FAMEX firms and } \\
\text { counterfactual is not significant }\end{array}$}} & & \\
\hline (b) Total counterfactual exports of all FAMEX firms without treatment (in millions of TD) & 896.53 & 881.67 & & & & & & \\
\hline (c) Additional exports generated by FAMEX program (in millions of TD) & 455.73 & 551.75 & & & & & & \\
\hline (d) Discounted (using 8\% rate) additional FAMEX exports (in millions of TD) & 455.73 & 507.61 & - & - & - & - & & \\
\hline (e) Total profits (using 5\% rate) generated by additional FAMEX exports (in millions of TD) & 22.79 & 25.38 & - & - & - & - & 48.17 & \\
\hline $\begin{array}{l}\text { (f) Tax revenue collected on total profits generated by additional FAMEX exports ( } 30 \% \\
\text { corporate tax rate) (in millions of TD) }\end{array}$ & 6.84 & 7.61 & - & - & - & - & 14.45 & \\
\hline $\begin{array}{l}\text { Total cost of grants provided to firms + administrative and operational costs of FAMEX } \\
\text { program (in millions of TD) }\end{array}$ & 14.20 & & & & & & 14.20 & \\
\hline (h) Public benefit/cost ratio $=(f) /(g)$ & & & & & & & & 1.02 \\
\hline (i) Net after-tax total profits generated by additional exports (in millions of TD) $=$ (e)-(f) & 15.95 & 17.77 & - & - & - & - & 33.72 & \\
\hline (j) Amount paid for by FAMEX firms as matching grants (in millions of TD) & 9.44 & & & & & & 9.44 & \\
\hline (k) Private benefit/cost ratio $=(i) /(j)$ & & & & & & & & 3.57 \\
\hline (l) Total public and private cost of FAMEX program $=(\mathrm{g})+(\mathrm{j})$ & 23.64 & & & & & & & \\
\hline (m) Overall benefit/cost ratio $=(e) /(l)$ & & & & & & & & 2.04 \\
\hline
\end{tabular}

Note: TD stands for Tunisian Dinar.

\section{Concluding remarks}

Trade promotion policies are increasingly popular, but evidence on their impact is limited, in particular beyond the short run. Our evaluation of the FAMEX export promotion program in Tunisia revealed positive short-run effects, as beneficiaries initially had higher total exports and greater diversification across destinations and products than a control group. However, three years after the intervention, treatment effects had vanished, with all of the treatment group's outcomes being statistically similar, in levels, to those of the control group.

We used the different dimensions of our dataset to look for possible reasons behind FAMEX's transient effects. First, we tried to identify spillovers to non-beneficiary firms, a potentially important consideration for a publicly-funded program. It could have been that treatment effects were transient not because of vanishing effects for beneficiary firms, but because of catching up by others as program benefits "leaked." In that case, vanishing treatment effects would be good news from a policy standpoint. However, estimated spillovers were either insignificant or negative. 
Macroeconomic factors like the global financial crisis and its consequences for the E.U., an important destination for Tunisian exports, did not seem to play a role either. Looking at factors like the characteristics of the FAMEX program (specific types of assistance) and those of beneficiary firms (size and the existence of an internal export unit) produced suggestive evidence. For instance, relatively shallow market prospection and promotion activities seemed to have a more discernible impact than deeper assistance to product and process upgrading. This may have reflected the program's deliberate emphasis, as sixty percent of aggregate FAMEX grants were used to co-finance the cost of activities related to market prospection and promotion, while much smaller amounts were devoted to firm and product development activities which may have required larger amounts to create more long-lasting benefits. Program impact was also more apparent for medium-sized firms (between 20 and 100 employees), and for those not having an internal export unit prior to the program, i.e., for the least "export-ready." Moreover, there was no sign of improvements in product quality and sophistication of FAMEX beneficiaries. In sum, the greater emphasis on, and greater success of, relatively basic export assistance may help explain why the FAMEX program did not durably enhance export competitiveness.

Whether our results should be construed as showing success or failure of FAMEX is open to debate. World Bank project documents used to advocate the program internally suggested that its promoters were expecting beneficiary firms to be put on a permanently different export growth trajectory. This does not seem to have happened on average. If one takes as yardstick, instead, an export boost of more than a dollar per dollar spent, our estimates suggest that the mission was accomplished, and by a margin that may have yielded positive benefits even taking more stringent performance outcome indicators such as incremental firm profits and government tax revenue. Given the break-even benefit-cost ratio for the government, it may even have been possible to run the program on a cost-recovery basis. However, the high benefit-cost ratio for the private sector may warrant a closer examination of the constraints that prevent firms from undertaking such export promotion activities unilaterally.

The results of specific impact evaluation exercises are notoriously hard to generalize. We too are not in a position to make a general pronouncement on the efficacy of export promotion measures in different contexts. Nevertheless, we feel that our analysis of why FAMEX produced short-lived benefits may have yielded some insights of broader relevance. In particular, basic assistance to address asymmetries of information about export markets may produce only temporary export blips. Given evidence from other research that many firms succeed in breaking into foreign markets but relatively few survive, policy makers may need to consider whether export assistance can promote not just entry but also durable presence in foreign markets. 
Last but not least, our work highlights the difficulties that lie in the way of identifying unambiguously the effect of firm assistance programs on the basis of quasi-experimental techniques. We hope that this paper will prompt governments and donors to design exportpromotion and other firm assistance programs in a way that makes them more amenable to impact evaluation. Even when randomized assignment of assistance to firms is not possible, other measures, such as scoring the applications and keeping track of the performance of firms whose applications were rejected, would greatly improve the quality of program evaluation.

\section{References}

Alvarez, R., and G. Crespi (2000). "Exporter Performance and promotion Instruments: Chilean Empirical Evidence"; Estudios de Economia 27, Universidad de Chile.

Aitken, B., Hanson, G., and A. Harrison (1997). "Spillovers, Foreign Investment and Export Behavior"; Journal of International Economics 43, 103-132.

Atkin, D., Khandelwal, A., and A. Osman (2015). "Exporting and Firm Performance: Evidence from a Randomized Trial”, NBER Working Paper 20690.

Bernard, A. and B. Jensen (2004). "Why Some Firms Export"; Review of Economics and Statistics $86,561-569$.

Bernard, A., Jensen, B., Redding, S., and P. Schott (2007). "Firms in International Trade”; Journal of Economic Perspectives 21, 105-130.

van Biesebroeck, Johannes; E. Yu and S. Chen (forthcoming): "The Impact of Trade Promotion Services on Canadian Exporter Performance"; Canadian Journal of Economics, forthcoming.

Blundell, R. and M. Costa Dias (2009). "Alternative Approaches to Evaluation in Empirical Microeconomics"; Journal of Human Resources 44, 565-640.

Cadot, O., Iacovone, L., Pierola, M., and F. Rauch (2013). "Success and Failure of African Exporters"; Journal of Development Economics 101, 284-296.

Chen, S., Mu, R. and M. Ravallion (2009). “Are There Lasting Impacts of Aid to Poor Areas?”; Journal of Public Economics 93, 512-528.

Dehejia, R. and S. Wahba (2002). "Propensity Score Matching Methods for Nonexperimental Causal Studies"; Review of Economics and Statistics 84, 151-161.

DiNardo, J., Fortin, N., and T. Lemieux (1996). "Labor Market Institutions and the Distribution of Wages, 1973-1992: A Semiparametric Approach"; Econometrica 64, 1001-1044.

Eaton, J., Kortum, S., and F. Kramarz (2011). "An Anatomy of International Trade: Evidence from French Firms"; Econometrica 79, 1453-1498.

Freund, C. and M. Pierola (forthcoming). "Export Superstars," Review of Economics and Statistics forthcoming. 
Girma, S., Gong, Y., Görg, H., and Z. Yu (2009). "Can Production Subsidies Explain China's Export Performance? Evidence from Firm-level Data"; Scandinavian Journal of Economics 111, 863-891.

Görg, H., Henry, M., and E. Strobl (2008). "Grant Support and Exporting Activity”; Review of Economics and Statistics 90, 168-174.

Gourdon, J., Marchat, J., Sharma, S. and T. Vishwanath (2011). "Can Matching Grants Promote Exports? Evidence from Tunisia's FAMEX Program"; in Cadot, O., Fernandes, A., Gourdon, J. and A. Mattoo (eds.) Where to Spend the Next Million? Applying Impact Evaluation to Trade Assistance; The World Bank and CEPR, pp. 81-106.

Hausmann, R. and D. Rodrik (2003). "Economic Development as Self-Discovery"; Journal of Development Economics 72, 603-633.

Hausmann, R., Hwang, J. and D. Rodrik (2007). "What you Export Matters”; Journal of Economic Growth 12, 1-25.

Heckman, J., Ichimura, H., and P. Todd (1997). "Matching as an Econometric Evaluation Estimator: Evidence from Evaluating a Job Training Programme"; Review of Economic Studies 64, 605-654.

Hirano, K. Imbens, G. and G. Ridder (2003). "Efficient Estimation of Average Treatment Effects Using the Estimated Propensity Score"; Econometrica 71, 1161-1189.

Holland, P. (1986). "Statistics and Causal Inference"; Journal of the American Statistical Association 81, 945-960.

Kneller, R. and M. Pisu (2007). "Industrial Linkages and Export Spillovers from FDI"; World Economy 30, 105-134.

Krautheim, S. (2012). "Heterogeneous Firms, Exporter Networks and the Effect of Distance on International Trade"; Journal of International Economics 87, 27-35.

Lederman, D., Olarreaga, M., and L. Payton (2010). "Export Promotion Agencies Revisited"; Journal of Development Economics 91, 257-265.

Mayneris, F. and S. Poncet (2010). "Export Performance of China's Domestic Firms: the Role of Foreign Export Spillovers"; Document de Travail No. 32, CEPII.

McDermott, M. (1994). “Is International Marketing a Game of Spy vs. Spy?”; Brandweek 35, June 20.

Rangan, S. and R. Lawrence (1999). "Search and Deliberation in International Exchange: Learning from International Trade about Lags, Distance Effects, and Home Bias"; NBER Working Paper 7012.

Ravallion, M. (2008). "Evaluation in the Practice of Development"; World Bank Policy Research Working Paper No. 4547.

Rose, A. (2007). "The Foreign Service and Foreign Trade: Embassies as Export Promotion"; The World Economy 30, 22-38.

Rosenbaum, P. and D. Rubin (1983). "The Central Role of the Propensity Score in Observational Studies for Causal Effects”; Biometrika 70, 41-55. 
Smith J. and P. Todd (2005). "Does Matching Overcome LaLonde's Critique of Nonexperimental Estimators? Journal of Econometrics 125, 305-353.

Volpe, C. and J. Carballo (2008). "Is Export Promotion Effective in Developing Countries? Firmlevel Evidence on the Intensive and Extensive Margins of Export Growth"; Journal of International Economics 76, 89-106.

Volpe, C. and J. Carballo (2010). "Beyond the Average Effects: The Distributional Impacts of Export-Promotion Programs in Developing Countries"; Journal of Development Economics 92, 201-214.

Van de Walle, D. and R. Mu (2007). "Fungibility and the Flypaper Effect of Project Aid: MicroEvidence for Vietnam"; Journal of Development Economics 84, 667-685.

World Bank (2004). Project Appraisal Document on a proposed loan in the amount of euro 30.3 million (U.S.\$ 36 million equivalent) to the Republic of Tunisia for second export development project. Washington, DC: The World Bank. 